\title{
ADAPTIVNí MATICOVÝ TEST Recenze metody
}

\author{
AUTOŘI RECENZE: AdAM Ť́́PAL ${ }^{1}$, VÍT GABRHEL ${ }^{2}$ \\ ${ }^{1}$ Katedra psychologie, Fakulta sociálních studií, Masarykova univerzita \\ ${ }^{2}$ Centrum dopravního výzkumu, v.v.i.
}

\begin{tabular}{|c|l|}
\hline \multicolumn{1}{|c|}{ datum vzniku recenze: } & 2. 8.2018 \\
\hline 1.1 název nástroje: & Adaptivní maticový test \\
\hline zkrácený název: & AMT \\
\hline 1.2 původní název: & Adaptive matrices test \\
\hline 1.4 autoři původního testu: & L. F. Hornke, S. Etzel \& K. Rettig \\
\hline 1.3 autoři lokální adaptace: & S. Hoskovcová \\
\hline 1.7 lokální distributor: & Assessment Systems Czech Republic \\
\hline $1.9 .1 / 1.9 .2$ datum vydání: & 2011 \\
\hline
\end{tabular}

\section{Obecné informace o metodě}

Adaptivní Maticový Test $(\mathrm{AMT})^{3}$ v rámci Vídeňského testového systému (VTS) je neverbální počítačově administrovanou metodou určenou k měření obecné inteligence, z hlediska CHC teorie (např. Carroll, 1993) k měření inteligence fluidní, konkrétně schopnosti induktivního usuzování. Test je určen pro neklinickou populaci v řadě kontextů, od dopravní psychologie přes personalistiku až po neuropsychologická vyšetření.

AMT je klasickým maticovým testem, kdy položky sestávají z doplňování devátého prvku z osmi nabízených možností do matice o velikosti $3 \times 3$ prvků. Administrace testu je relativně rychlá (typicky do 60 minut), avšak vzhledem k počítačové administraci a adaptivnímu mechanismu selekce položek se délka testu (resp. počet administrovaných položek) u jednotlivých administrací zpravidla liší. Typická délka

\footnotetext{
1 Masarykova univerzita, Fakulta sociálních studií, Katedra psychologie; Joštova 10, 60200 Brno.

2 Centrum dopravního výzkumu, v.v.i. , Líšeňská 33a, 63600 Brno.

3 Tento článek byl vytvořen za finanční podpory Ministerstva školství, mládeže a tělovýchovy v rámci programu Národní program udržitelnosti I, projektu Dopravní VaV centrum (L01610) na výzkumné infrastruktuře pořízené z Operačního programu Výzkum a vývoj pro inovace (CZ.1.05/2.1.00/03.0064).
} 
administrace je ovlivněna především volbou jedné ze čtyř nabízených forem, které se odlišují v zamýšlené přesnosti měření. Jedna z forem je také časově omezena 20 minutami pro řešení úloh. Skórování je prováděno automaticky počítačovým programem.

Test byl standardizován na souboru 1356 rakouských respondentů, normy byly vytvořeny za pomoci souboru o velikosti 461 respondentů z téhož prostředí.

\section{Administrace a skórování}

Administrace testu je relativně jednoduchá, stejně jako nároky na ovládání počítačového rozhraní probandem a jeho porozumění obsahu testu. Administrace probíhá kompletně skrze softwarové testové rozhraní, včetně předání úvodních instrukcí pro práci s testem probandovi. Součástí administrace jsou také neskórované zácvičné položky, které mají zajistit dostatečné seznámení probanda s principem prezentovaných úloh, s ovládáním testového rozhraní i s formátem odpovídání.

Po dokončení testu je k dispozici vygenerovaná zpráva s výsledným skórem a jeho percentilovým ekvivalentem. Zpráva obsahuje i dílčí informace (celková délka testování, počet administrovaných položek, průběh testování atd.), interpretace je však k dispozici pouze ve stručné podobě. Skóry, které test poskytuje, jsou odhady probandovy latentní úrovně měřeného rysu (parametr $\theta$ ). Tyto skóry lze chápat jako víceméně ekvivalentní z-skórům.

\section{Technické parametry}

\section{Reliabilita}

Vzhledem k adaptivnímu charakteru testu je možno předem zvolit zamýšlenou reliabilitu (respektive chybu odhadu latentního skóru), a to selekcí jedné z nabízených předdefinovaných forem testu.

Testová forma S1 (Screeningová) je ukončena ve chvíli, kdy nejistota ohledně odhadu úrovně schopnosti je ekvivalentní reliabilitě 0,7 ; forma S2 (Standardní) má dosáhnout reliability 0,83; forma S3 (Dlouhá) reliability 0,86; forma S11 je pak co do přesnosti ekvivalentní formě $\mathrm{S} 1$, avšak počáteční položky jsou průměrně jednodušší v porovnání $\mathrm{s}$ formou $\mathrm{S} 1$ a jako u jediné je u této formy omezena délka administrace na max. 20 minut. Forma S11 je dle autorů určena pro účely dopravně-psychologických vyšetření.

V závislosti na volbě formy, konzistenci výkonu probanda a úrovně měřeného rysu probanda tak lze očekávat různé délky administrace. Maximální počet položek v jedné administraci je stanoven na 30, resp. 35 položek (manuál metody zmiňuje obě hodnoty). Anglická verze manuálu také uvádí dvě hodnoty test-retestové reliability formy S1 získané prostřednictvím studie o 82 zkoumaných osobách - stabilitu po třech měsících $(\mathrm{r}=0,62)$, a retestovou reliabilitu $(\mathrm{r}=0,74)$. Ve druhém př́padě se patrně jedná o opakovanou administraci ihned po administraci první, avšak manuál tyto parametry neupřesňuje. 


\section{Normy}

Dle informací z anglické verze manuálu (v české verzi informace o normách zcela chybí) byly normy vytvořeny na základě souboru 461 osob (220 mužů a 241 žen) ve věku mezi 18 a 81 lety. Bližší informace o věkové struktuře chybí, uveden je pouze průměrný věk (37 let) a směrodatná odchylka (14,5 let). Není známo, jakým způsobem byly osoby do souboru vybírány, je pouze známo, že sběr dat se uskutečnil v letech 2005 a 2006 vlaboratořích autorů testu $\mathrm{v}$ Rakousku. Nejsou uvedeny informace o struktuře zkoumaného souboru z hlediska stupně dosaženého vzdělání, národnosti či frekvence zastoupení různých věkových skupin. Vzhledem $\mathrm{k}$ absenci českých norem, respektive vzhledem $\mathrm{k}$ chybějícím informacím o standardizačním souboru, ze kterého byly zahraniční normy vytvořeny, nelze posoudit otázky reprezentativnosti norem v českém kontextu. Každý proband je také srovnáván se všemi osobami z normalizačního souboru bez ohledu na věk, přičemž nelze předpokládat, že distribuce měřeného rysu je napříč věkovými skupinami $v$ populaci stejná. Práce s normami je z těchto důvodů problematická - nelze bez výhrady srovnávat „české“ probandy s blíže nespecifikovanou rakouskou normou, schopnost např. starších osob také bude s největší pravděpodobností systematicky podhodnocována (vzhledem knestratifikovanosti norem dle věku). Podobně chybí také informace o proceduře standardizace testu. Manuál se rovněž nevěnuje otázce férovosti testu či diferenciálního fungování položek. Tuto problematiku pouze shrnuje konstatováním, že „dosavadní zkušenosti indikují, že test AMT je férový“, bez další uvedené podpory pro toto tvrzení.

\section{Validita}

Ačkoliv neexistuje mnoho explicitních důvodů, proč mít o kvalitách testu pochyb, je potřeba poznamenat, že kvalita samotné dokumentace je velmi nízká. Samotný český manuál k metodě je zcela nedostatečný a omezený, jeho anglicky psaná předloha však dostatečnému množství informací a dokladů o kvalitě metody rovněž neoplývá. Zcela chybí podrobnější informace o vývoji testu a položkové analýze, stejně jako ucelený souhrn důkazů obsahové a konstruktové validity. Chybí také podrobnější údaje o průběhu standardizace či o výběru standardizačního i normalizačního souboru, na což ostatně poukazujeme už v sekci „Normy“. Jak česky, tak anglicky psaný manuál odkazuje na časopiseckou studii, která tyto informace s největší pravděpodobností alespoň částečně obsahuje, ta je nicméně psaná německy. Nelze tedy očekávat, že lokální uživatel metody bude mít k těmto informacím snadný přístup. Nemluvě o tom, že publikace není volně dostupná.

V manuálu autoři parafrázují konkrétní zjištění - korelaci odhadnutých obtížností položek s konstrukčním kritériem, které samotné rovněž uvádí jako důkaz obsahové validity. Volba tohoto kritéria však v manuálu není žádným zpơsobem vysvětlena. Jako další důkaz konstruktové validity AMT odkazují autoři anglické verze manuálu na studii (Sommer a Arendasy, 2005), která se zabývala otázkou struktury inteligence (respektive ověřovala $\mathrm{CHC}$ model inteligence) a jako jednu z manifestních proměnných pro faktor fluidní inteligence používala právě AMT. Na tento důkaz lze tedy nahlížet jako na variaci MTMM studie, avšak dle našeho soudu nelze tento zdroj považovat za samostatně 
uspokojivý důkaz konstruktové validity ATM. Nehledě na to, že popis samotné studie zaujímá neúměrně velký prostor v manuálu.

Co se kriteriální validity týče, anglicky psaný manuál odkazuje na dvě studie, ani v jednom případě však nelze hovořit o uspokojivém důkazu kriteriální validity. $V$ jednom př́ṕpadě je AMT zmíněn jako součást testové baterie, která úspěšně diskriminuje mezi řidiči s historií nehod a bez ní (z těchto závěrů je usuzováno na kriteriální validitu), přičemž skór z AMT mírně pozitivně koreluje s celkovým zhodnocením řidičských schopností. $V$ druhém případě je AMT zmíněn opět jako součást testové baterie při zkoumání výkonu uchazečů na leteckém simulátoru, přičemž tato baterie je prezentována jako vysoce informativní prediktor úspěšnosti uchazeče v simulátorovém scénáři. Ani jeden důkaz však nelze považovat za standardní typ důkazu kriteriální validity testu obecné inteligence, respektive autoři metody $\mathrm{v}$ manuálu volbu obou indikátorů neargumentují. Oba důkazy lze považovat za ukazatel prediktivní validity metody v kontextu dopravně-psychologického vyšetření, avšak bez dostatečných důkazů o konstruktové validitě mají převážně jen empirickou hodnotu. Z některých publikovaných studií, které v manuálu citovány nejsou, lze obohatit informace o prediktivní validitě testu. Ve studii z roku 2008 (Sommer et al.) nebyl na vzorku 127 osob identifikován věcně významný vztah $(r=-0,12)$ mezi výkonem v AMT a výkonem ve standardizovaném řidičském testu. Risser et. al (2008) použili AMT v rámci dopravně-psychologické baterie k predikci výkonu ve standardizovaném řidičském testu prostřednictvím aplikace neuronové sítě. Ačkoliv výkon v AMT byl relevantním prediktorem výkonu, je z textu patrné, že po zařazení testu distribuce pozornosti mezi prediktory znatelně poklesla inkrementální validita AMT.

\section{Shrnutí}

Test AMT využívá řady předností moderních psychometrických postupů (adaptivní testování, dosažení shodné úrovně přesnosti měření nezávisle na úrovni měřeného rysu, ochrana položkové banky před nadměrnou expozicí apod.) a pro administrátora testu je uživatelsky př́ijemnou metodou. Nabízí čtyři formy, které se liší typickou délkou a zamýšlenou přesností měření, poskytované skóry jsou odhady měřeného latentního rysu. Počítačové rozhraní pro administraci také generuje stručné výsledné zprávy, obsahující kromě skóru také jeho percentilový ekvivalent a další dílčí informace (délka a průběh testování, počet administrovaných položek apod.).

Test, respektive testová příručka, kterou čtenář dostává spolu s testem k dispozici (jak včeské, tak anglické verzi), však trpí řadou nedostatků. Česká verze manuálu je z hlediska poskytování úplných a kvalitních informací pro uživatele testu zcela nedostatečná. Chybí informace o reliabilitě vyjma vnitřní konzistence, o důkazech validity, o normách, o procesu vývoje testu a jednotlivých položek či informace spojené s položkovou analýzou. Česká verze manuálu obsahuje řadu chyb, překlepů a formálních nedostatků, místy působí jako strojový překlad anglické verze příručky. Pro uživatele testu, který stojí o získání potřebných informací v českém jazyce, je manuál naprosto nedostačujícím zdrojem. Ani anglický manuál však není závažných (ale i formálních) 
nedostatků zcela prostý. Snad největším nedostatkem jsou chybějící či neúplné informace o teoretických principech metody a o jejím vývoji, včetně konstrukce a analýzy položek. Autoři testu odkazují na vlastní časopisecký článek, ve kterém má být řada těchto informací uvedena, avšak tento článek je publikován v placeném periodiku a je psán v německém jazyce. Pro českého uživatele bez znalosti německého jazyka (kterou v žádném případě nelze paušálně očekávat) je tedy manuál jako zdroj těchto informací nedostačující.

Stejné výtky lze adresovat směrem $\mathrm{k}$ absenci přesvědčivých důkazů o validitě metody. Jedinými prezentovanými důkazy o validitě jsou odkazy na studie, provedené jinými autory, než kteří metodu vyvíjeli, a to ještě $v$ nedostatečném rozsahu. To čtenáři znemožňuje posoudit důkazy o validitě metody. Obsahová validita je téměř nekomentována, důkaz o konstruktové validitě je představen pouze ve formě odkazu na jedinou studii, která však nemůže dostatečné důkazy o konstruktové validitě poskytnout. Jedná se totiž o výzkum struktury inteligence ve formě testování různých faktorových modelů (skór z AMT figuruje jako jedna z pozorovaných proměnných). Kriteriální validita je dokazována odkazy na studie dvě, z nichž však ani jedna neposkytuje kritéria vhodná k posouzení validity testu fluidní inteligence (jedním z kritérií je nehodovost řidičů a řidičské schopnosti, druhým z kritérií je výkon osob v leteckém simulátoru). Po doplnění informací z (anglicky psaných) časopiseckých zdrojů neuvedených v manuálu metody však rovněž nelze být s důkazy o kriteriální validitě testu přesvědčen.

Z hlediska poskytnutých informací o konstrukci norem, resp. o normalizačním vzorku, se v obou manuálech metody nesetkáváme s mnohým. Podrobnější složení vzorku není známo a normy jsou pouze obecné, nesrovnávají participanta s žádnou užší demografickou skupinou. To představuje ohrožení validity norem a férovost užití testu.

\section{Doporučení}

Na testu AMT lze ocenit inovativnost, př́ijemnost použití, adaptivní povahu a (tušené) solidní racionále pro tvorbu položek a předpokládané fungování testu. Testové materiály jsou však neadekvátní a působí nedokončeným dojmem - především česká verze manuálu, kterou rozhodně nelze doporučit pro užívání. 0 validitě testu nemůže být uživatel na základě poskytnutých informací zcela přesvědčen, problematické je však také použití norem. V českém prostředí by byl proband srovnáván s nejasně specifikovanou skupinou osob testovaných v Rakousku, a s největší pravděpodobností by jeho výkon nebyl férově srovnáván s pro něj vhodnou referenční skupinou. Z uvedených důvodů tedy doporučujeme užívat test AMT jen velmi obezřetně k orientačnímu měření fluidní inteligence - alespoň do chvíle, kdy bude manuál testu doplněn o informace, které získání důvěry v deklarované kvality testu náležitě podpoří. 


\section{Zdroje}

Carroll, J.B. (1993). Human cognitive abilities: A survey of factor-analytic studies. Cambridge, England: Cambridge University Press.

Risser, R., Chaloupka, C., Grundler, W., Sommer, M., Häusler, J., \& Kaufmann, C. (2008). Using nonlinear methods to investigate the criterion validity of traffic-psychological test batteries. Accident Analysis \& Prevention, 40(1), 149-157.

Sommer, M. \& Arendasy, M. (2005). Theory-based construction and validation of a modern computerized intelligence test battery. Budapest: EAPA 2005 Abstracts.

Sommer, M., Herle, M., Häusler, J., Risser, R., Schützhofer, B., \& Chaloupka, C. (2008). Cognitive and personality determinants of fitness to drive. Transportation Research Part F: Traffic Psychology and Behaviour. http://doi.org/10.1016/j.trf.2008.03.001 


\section{MODEL RECENZE PODLE EFPA PRO POPIS \\ A HODNOCENÍ PSYCHOLOGICKÝCH TESTŮ \\ FORMULÁŘ RECENZE TESTU A POZNÁMKY PRO \\ RECENZENTY ${ }^{1}$}

Toto je lokální úprava dokumentu pro účely publikace v časopise Testfórum.

Originální český překlad je k dispozici na stránkách EFPA

(www.efpa.eu/download/505cd9db4144ecb16174087909c9cd6d).

Původní verzi sestavil a uspořádal Dave Bartram

Doplnili a revidovali Patricia Lindley, Dave Bartram a Natalie Kennedy v dubnu $2004^{2}$

Současná verze 3.42: květen 2005

Český překlad: Tomáš Urbánek

Od uživatelů tohoto dokumentu a jeho obsahu žádá EFPA, aby uznali tento zdroj prostřednictvím následujícího textu:

"Kritéria pro recenzi testu podle EFPA do značné míry vychází z formy a obsahu kritérií pro recenze testů Britské psychologické společnosti (BPS) a kritérií vytvořených Komisí pro testové záležitosti (COTAN) Holandské asociace psychologů (NIP). Dave Bartram a Patricia Lindley původně vyvinuli kritéria BPS a recenzní procedury pro UK Employment Service a později rozšírili jejich používání pro celou BPS. Arne Evers připravil k vydání nizozemský system posuzování kvality testů.

EFPA je vděčná BPS a NIP za svolení použít jejich kritéria jako základ pro vytvoření evropského modelu. EFPA je také vděčná Davu Bartramovi, Arnu Eversovi a Patricii Lindley za jejich přispění $k$ vývoji tohoto modelu. Veškerá intelektuální vlastnická práva původních kritérií podle BPS a NIP jsou nadále uznávána a náleží těmto orgánům."

\footnotetext{
1 Tento dokument byl vytvořen z několika zdrojů, včetně Hodnotícího formuláře pro recenzi testu používaného v BPS (NPAL a Řídící komise pro testové standardy při BPS - Steering Committee on Test Standards), Španělského dotazníku pro hodnocení psychometrických testů (Španělská psychologická asociace) a Systému pro posuzování kvality testu (Komise pro testování Holandské asociace psychologů). Některé části byly adaptovány se svolením z dokumentu: BPS Books Reviews of Level B Assessment Instruments for use in Occupational Assessment, Notes for Reviewers: Version 3.1. December 1998: Copyright (C) NPAL, 1989, 1993, 1998.

2 Současná verze je spojením dvou oddělených dokumentů (Formuláře recenze a Poznámek pro recenzenty). Obsah byl navíc uspořádán a doplněn na základě jeho používání recenzenty online testů v BPS.
} 


\section{Část 1:}

Popis nástroje: Obecné informace a klasifikace

\begin{tabular}{|c|c|c|}
\hline & Recenzent 1: & Mgr. Adam Ťápal, M.A. \\
\hline & Recenzent 2: & Mgr. Vít Gabrhel \\
\hline & Konzultující editor: & Mgr. Hynek Cígler, Ph.D. \\
\hline & Vedoucí editor: & Mgr. Hynek Cígler, Ph.D. \\
\hline & $\begin{array}{l}\text { Vedoucí editor aktualizace: } \\
\text { (pouze v př́ípadě aktualizací) }\end{array}$ & \\
\hline & $\begin{array}{l}\text { Editor aktualizace: } \\
\text { (pouze v př́ipadě aktualizací) }\end{array}$ & \\
\hline & Datum vzniku této recenze: & 2. 8. 2018 \\
\hline \multirow[t]{2}{*}{1.1} & Název nástroje (lokální verze): & Adaptivní maticový test \\
\hline & Zkrácená verze názvu testu: & AMT \\
\hline 1.2 & $\begin{array}{l}\text { Původní název testu (pokud je lokální } \\
\text { verze adaptací): }\end{array}$ & Adaptive matrices test \\
\hline 1.4 & Autoři původního testu: & L. F. Hornke, S. Etzel \& K. Rettig \\
\hline 1.3 & Autoři lokální adaptace: & S. Hoskovcová \\
\hline 1.7 & Lokální distributor/vydavatel testu: & Assessment Systems Czech Republic \\
\hline 1.8 & $\begin{array}{l}\text { Vydavatel původní verze testu (pokud je } \\
\text { jiný než současný distributor/vydavatel): }\end{array}$ & Schuhfried GmBH \\
\hline 1.9 .1 & Datum vydání současné revize/vydání: & 2011 \\
\hline 1.9 .2 & $\begin{array}{l}\text { Datum vydání adaptace pro lokální } \\
\text { užívání: }\end{array}$ & 2011 \\
\hline 1.9 .3 & Datum vydání původního testu: & 2011 \\
\hline
\end{tabular}




\section{Obecný popis nástroje}

Adaptivní Maticový Test (AMT) je neverbální počítačově administrovanou metodou určenou k měření obecné inteligence, $\mathrm{z}$ hlediska CHC teorie (např. Carroll, 1993) k měření inteligence fluidní, konkrétně schopnosti induktivního usuzování. Test je určen pro neklinickou dospělou populaci (dle manuálu dokonce od 13 let, avšak informace se různí). AMT je klasickým maticovým testem, kdy proband volí vhodný devátý prvek k doplnění do matice prvků o velikosti $3 \times 3$ - nabízených alternativ pro každou položku je celkem 8. Adaptivní charakter testu se projevuje sekvenční administrací jednotlivých položek, kdy každá následující položka je zvolena z položkové banky tak, aby její vyřešení (či nevyřešení) bylo co nejvíce informativní vzhledem k dosavadním odpovědím probanda (a tedy dosavadnímu odhadu probandovy schopnosti). Žádnému probandovi by tak neměly být administrovány položky, které jsou na základě jeho dosavadního výkonu považovány za pro tohoto probanda př́liš jednoduché nebo př́liš obtížné. Adaptivnost testu má za důsledek různorodou délku testu pro každého probanda. Délku testu je dále možno do jisté míry ovlivnit volbou formy testu - k dispozici jsou jak formy kratší (a tedy méně přesné), tak formy delší. Pouze jedna ze čtyř dostupných forem testu je časově omezena. Dle manuálu lze AMT využít v celé řadě kontextů, např́íklad v oblasti selekce pracovníků, dopravní a letecké psychologie, klinické psychologie či v oblasti vzdělávání a karierního poradenství.

\section{Část 2: \\ Klasifikace}

\begin{tabular}{|c|c|c|}
\hline 1.10 .1 & Obsahová doména & $\begin{array}{ll} & \text { Školní schopnosti } \\
\square & \text { Všeobecné schopnosti } \\
\square & \text { Verbální schopnosti } \\
\square & \text { Numerické schopnosti } \\
\square & \text { Prostorové schopnosti } \\
\square & \text { Neverbální schopnosti } \\
\square & \text { Rychlost vnímání } \\
\square & \text { Pamět' } \\
\square & \text { Manuální zručnost } \\
\square & \text { Osobnost - Rys } \\
\square & \text { Osobnost - Typ } \\
\square & \text { Osobnost - Stav } \\
\square & \text { Kognitivní styly } \\
\square & \text { Motivace } \\
\square & \text { Hodnoty } \\
\square & \text { Zájmy } \\
\square & \text { Přesvědčení } \\
\square & \text { Poruchy a patologie } \\
\square & \text { Skupinové procesy } \\
\square & \text { Rodina } \\
\square & \text { Organizace, její fungování, agregovaná } \\
\text { měření, klima atd. } \\
\square \text { Školní nebo výchovné funkce } \\
\square \text { Jiné: }\end{array}$ \\
\hline
\end{tabular}




\begin{tabular}{|c|c|c|}
\hline 1.10 .2 & $\begin{array}{l}\text { Zamýšlená(é) nebo hlavní oblast(i) } \\
\text { použití. }\end{array}$ & $\begin{array}{ll}\bigotimes & \text { Klinická psychologie } \\
\bigotimes & \text { Neuropsychologie } \\
\square & \text { Forenzní psychologie } \\
\bigotimes & \text { Psychologie výchovy a vzdělávání } \\
\bigotimes & \text { Psychologie práce a personalistika } \\
\bigotimes & \text { Poradenství, doporučení, vedení a volba } \\
& \text { povolání } \\
\bigotimes & \text { Psychologie zdraví, životní styl a životní } \\
& \text { spokojenost } \\
\bigotimes & \text { Sporty a volný čas } \\
\bigotimes & \text { Jiné: } \\
& \text { Dopravní psychologie }\end{array}$ \\
\hline 1.10 .3 & $\begin{array}{l}\text { Zamýšlený způsob použití } \\
\text { (podmínky, za jakých byl nástroj } \\
\text { standardizován a validizován) }\end{array}$ & $\begin{array}{l}\text { Nesupervidovaná administrace bez } \\
\text { kontroly nad identitou respondenta a bez } \\
\text { úplné kontroly nad podmínkami } \\
\text { administrace (např. volně př́stupný test } \\
\text { na internetu, test dostupný ke koupi v } \\
\text { knihkupectví). } \\
\text { Kontrolovaný nesupervidovanou } \\
\text { administrcí. Kontrola nad podmínkami } \\
\text { (čas atd.) a určitá kontrola nad identitou } \\
\text { uživatele testu (např. testy } \\
\text { administrované přes internet, ale pouze } \\
\text { známým osobám - př́ístup omezený } \\
\text { heslem). } \\
\text { Supervidovaná a kontrolovaná } \\
\text { administrace. Administrace testu pod } \\
\text { kontrolou kvalifikovaného adminitrátora } \\
\text { nebo dohlíziitele. } \\
\text { Řízená administrace. Administrace testu } \\
\text { prováděná pouze přes určená testovací } \\
\text { centra (např. programy hodnocení licencí } \\
\text { a certifikace). }\end{array}$ \\
\hline 1.10 .4 & $\begin{array}{l}\text { Popis populací, pro které je test } \\
\text { určen: }\end{array}$ & Dospělí a mládež nad 16 let \\
\hline 1.10 .5 & $\begin{array}{l}\text { Počet škál a krátký popis } \\
\text { proměnné nebo proměnných } \\
\text { měřených nástrojem }\end{array}$ & Obecná inteligence \\
\hline 1.11 & Formát položek & $\begin{array}{ll} & \text { Otevřený } \\
\bigotimes & \text { Mnohonásobná volba, alternativy na } \\
& \text { stejné škále } \\
\square & \text { Bipolární adjektiva } \\
\square & \text { Likertovy ratingy (škály) } \\
\square & \text { Nucená volba, alternativy na smíšených } \\
\text { škálách (ipsativní) - vysvětlení viz } \\
\text { Poznámky } \\
\square \text { Mnohonásobná volba, alternativy na } \\
\text { smíšených škálách (ipsativní) - } \\
\text { vysvětlení viz Poznámky } \\
\square \text { Sady párů adjektiv (sémantický } \\
\text { diferenciál), smíšené škály (ipsativní) } \\
\square \text { Jiné: }\end{array}$ \\
\hline 1.12 & Počet položek testu: & $\begin{array}{l}\text { Variabilní; v hlavní fázi testování maximálně } \\
30 \text { nebo } 35 \text { (informace v manuálu se rozchází) }\end{array}$ \\
\hline
\end{tabular}




\begin{tabular}{|c|c|c|c|c|}
\hline 1.13 & Způsob(y) administrace: & $\begin{array}{l}\square \\
\square \\
\square \\
\square \\
\square \\
\square \\
\square\end{array}$ & \multicolumn{2}{|c|}{$\begin{array}{l}\text { Interaktivní individuální administrace } \\
\text { Supervidovaná skupinová administrace } \\
\text { Počítačová lokálně nainstalovaná } \\
\text { aplikace - pod supervizí/dohledem } \\
\text { Počítačová aplikace na webu - pod } \\
\text { supervizí/dohledem } \\
\text { Počítačová lokálně nainstalovaná } \\
\text { aplikace - bez supervise/testování sebe } \\
\text { Počítačová aplikace na webu - bez } \\
\text { supervize/testování sebe } \\
\text { Jiné: }\end{array}$} \\
\hline 1.14 & Způsob odpovídání: & $\begin{array}{l}\square \\
\square \\
\square \\
\square \\
\square\end{array}$ & \multicolumn{2}{|c|}{$\begin{array}{l}\text { Ústní rozhovor } \\
\text { Papír a tužka } \\
\text { Manuální operace } \\
\text { Na počítači } \\
\text { Jiné: }\end{array}$} \\
\hline 1.15 & $\begin{array}{l}\text { Čas potřebný pro administraci } \\
\text { nástroje: } \\
\text { Čas na př́ípravu (čas, který zabere } \\
\text { administrátorovi připravit a rozložit } \\
\text { materiály pro diagnostické sezení). } \\
\text { • Čas na administraci na sezení: zahrnuje } \\
\text { čas potřebný pro dokončení v̌̌ech } \\
\text { položek a odhad času potřebného pro } \\
\text { podání instrukcí, projití zácvičných } \\
\text { položek a nějaké doplňující komentáře } \\
\text { na konci sezení. } \\
\text { - Skórování: čas nutný pro získání } \\
\text { hrubých skórů. } \\
\text { - Analýza: čas strávený prováděním } \\
\text { dalších prací s hrubými skóry, aby se z } \\
\text { nich odvodily další míry a zformulovala } \\
\text { rozumně úplná interpretace (za } \\
\text { předpokladu, že znáte nástroj). } \\
\text { Zpětná vazba: čas potřebný k přípravě a } \\
\text { poskytnutí zpětné vazny vyšetřované } \\
\text { osobě. } \\
\text { Připouští se, že čas posledních dvou } \\
\text { komponent se múže značné lišit - v závislosti } \\
\text { na kontextu, ve kterém se nástroj používá. } \\
\text { Ale assonon nějaké údaje a komentáŕe budou } \\
\text { užitečné. }\end{array}$ & & $\begin{array}{l}\text { Příprava: } \\
\text { Administrace: } \\
\text { Skórování: } \\
\text { Analýza: } \\
\text { Zpětná vazba: } \\
\text { Test je adaptivn } \\
\text { forem, které se } \\
\text { přesnosti měřeı } \\
\text { časově omezenz } \\
\text { V závislosti na v } \\
\text { výkonu probanc } \\
\text { rysu probanda l } \\
\text { administrace. Sl } \\
\text { automaticky po } \\
\text { čas strávený na } \\
\text { množství inforn } \\
\text { administrátor z }\end{array}$ & $\begin{array}{l}\text { v řádu minut } \\
20 \text { - } 65 \text { minut } \\
0 \text { minut } \\
5 \text { minut } \\
5 \text { minut } \\
\text { ní a obsahuje několik } \\
\text { liší cílovou úrovní } \\
\text { ní. Jedna z forem je také } \\
\text { a } 20 \text { minutami. } \\
\text { volbě formy, konzistenci } \\
\text { da a úrovně měřeného } \\
\text { lze očekávat různé délky } \\
\text { kórování je prováděno } \\
\text { cćitačovým programem, } \\
\text { d analýzou závisí na } \\
\text { mací, které chce } \\
\text { získat. }\end{array}$ \\
\hline
\end{tabular}




\begin{tabular}{|c|c|c|}
\hline 1.16 & $\begin{array}{l}\text { Jsou k dispozici různé formy } \\
\text { nástroje? }\end{array}$ & $\begin{array}{l}\text { Test poskytuje čtyři formy, které se } \\
\text { většinově liší pouze v jednom aspektu, a } \\
\text { sice zamýšlené přesnosti měření (a tedy i } \\
\text { očekávané délce testování). Testová } \\
\text { forma S1 (Screeningová) je ukončena ve } \\
\text { chvíli, kdy nejistota ohledně odhadu } \\
\text { úrovně schopnosti je ekvivalentní } \\
\text { reliabilitě } 0,7 \text {; forma S2 (Standardní) má } \\
\text { dosáhnout reliability } 0,83 \text {; forma S3 } \\
\text { (Dlouhá) reliability 0,86; forma S11 je pak } \\
\text { co do přesnosti ekvivalentní formě S1, } \\
\text { avšak počáteční položky jsou prüměrně } \\
\text { jednodušší v porovnání s formou S1 a jako } \\
\text { u jediné je u této formy omezena délka } \\
\text { administrace na max. } 20 \text { minut. Forma } \\
\text { S11 je dle autorů určena pro účely } \\
\text { dopravně-psychologických vyšetření. }\end{array}$ \\
\hline
\end{tabular}

Č́ást 3:

Měření a skórování

\begin{tabular}{|c|c|c|}
\hline 1.17 & Procedura skórování testu: & 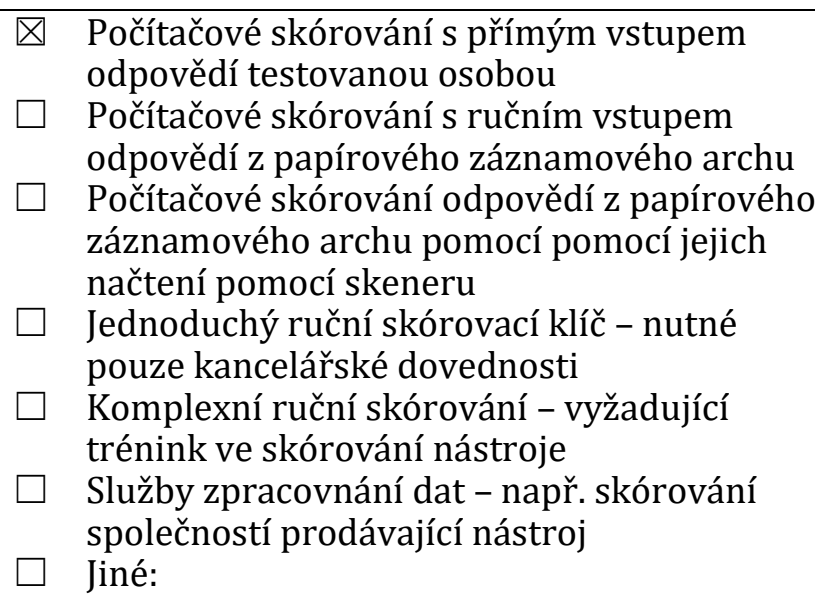 \\
\hline 1.18 & Skóry: & $\begin{array}{l}\text { Skóry, které test poskytuje, jsou odhady } \\
\text { probandovy latentní úrovně měřeného rysu } \\
\text { (parametr } \theta \text { ). Tyto skóry lze chápat jako } \\
\text { víceméně ekvivalentní z-skórům. Poskytnut je } \\
\text { také percentilový skór odpovídající pozici } \\
\text { probanda vzhledem k normě. }\end{array}$ \\
\hline 1.19 & $\begin{array}{l}\text { Transformace skóru na standardní } \\
\text { skóry: }\end{array}$ & $\begin{array}{ll}\square & \text { Normalizovaná - skóry se získají použitím } \\
\text { normalizační tabulky } \\
\square \\
\text { Nenormalizovaná - skóry se získají lineární } \\
\text { transformací }\end{array}$ \\
\hline
\end{tabular}




\begin{tabular}{|c|c|c|}
\hline 1.20 & Použité škály & 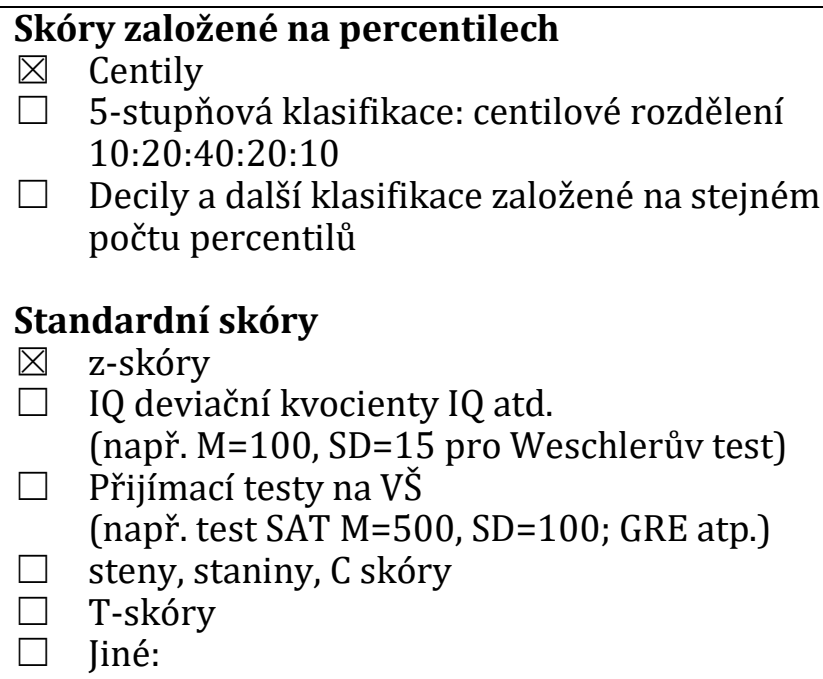 \\
\hline
\end{tabular}

Část 4:

Počítačově generované zprávy

Toto je čistě popisné. Hodnocení zpráv bude součástí části recenze nazvané Hodnocení.

\begin{tabular}{|l|l|ll|}
\hline 1.21 & $\begin{array}{l}\text { Jsou počítačově generované zprávy } \mathbf{k} \\
\text { dispozici s nástrojem? }\end{array}$ & $\bigotimes \quad$ Ano \\
$\square \mathrm{Ne}$ \\
\hline
\end{tabular}

\begin{tabular}{|c|c|c|}
\hline 1.21 .0 & Název nebo popis zprávy: & Výsledná zpráva \\
\hline 1.21 .1 & $\begin{array}{l}\text { Média: } \\
\text { Zprávy mohou sestávat pouze z textu nebo obsahovat } \\
\text { text spolu s grafickými nebo tabulkovými zobrazeními } \\
\text { skórú (napřs stenovými profilyy. Kde jsou prezentovány } \\
\text { text i data, mohou být prezentovány prostě paralelně, } \\
\text { nebo mohou být propojeny, takže vztah mezi textovými } \\
\text { výroky a skóry je explicitně vyjádřen. }\end{array}$ & $\begin{array}{ll} & \text { Pouze text } \\
\square & \text { Text a grafika bez vzájemného vztahu } \\
\bigotimes \quad \text { Integrovaný text a grafika }\end{array}$ \\
\hline 1.21 .2 & $\begin{array}{l}\text { Komplexnost: } \\
\text { Některé zprávy jsou velmi jednoduché, např. pouze } \\
\text { nahrazují kusem textu stenový skór v popisech } \\
\text { jednotlivých škál. Jiné jsou komplexněšsí, zahrnující části } \\
\text { textu, které jsou ve vztahu ke vzorcưm nebo } \\
\text { konfiguracím skórư škál a které berou v úvahu vliv } \\
\text { interakcí škál. }\end{array}$ & 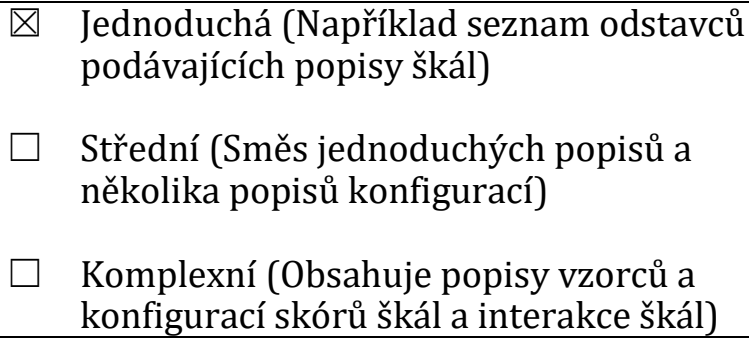 \\
\hline
\end{tabular}




\begin{tabular}{|c|c|c|}
\hline 1.21 .3 & $\begin{array}{l}\text { Struktura zprávy: } \\
\text { Struktura má vztah ke komplexitě. }\end{array}$ & 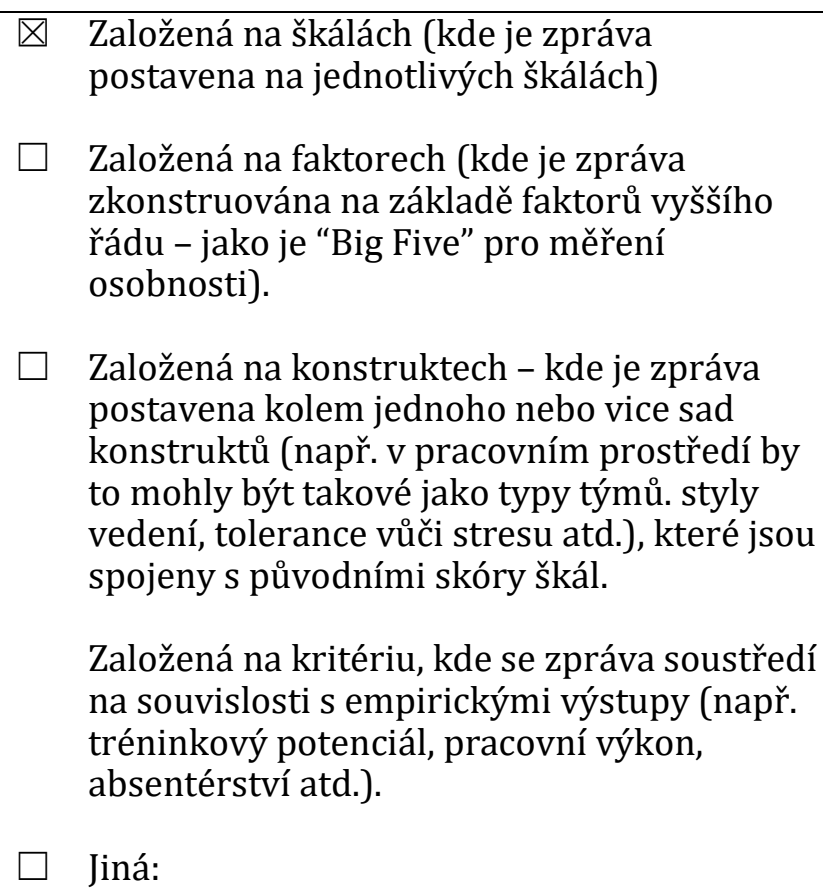 \\
\hline 1.21 .4 & 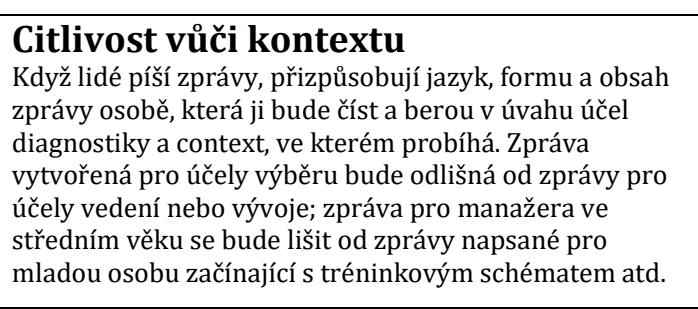 & $\begin{array}{ll}\square & \text { Jedna verze pro všechny kontexty } \\
\square \quad \text { Předdefinované verze pro různé kontexty } \\
\square \quad \begin{array}{l}\text { Uživatelem definovatelné kontexty } \\
\text { a editovatelné zprávy }\end{array}\end{array}$ \\
\hline 1.21 .5 & 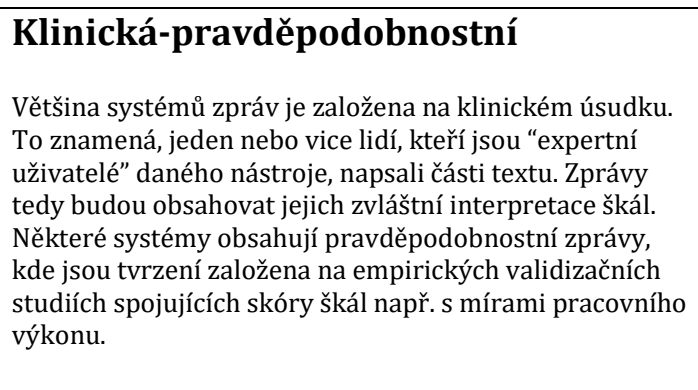 & $\begin{array}{ll}\square \quad \text { Založena na klinickém úsudku jednoho } \\
\text { experta } \\
\square \quad \begin{array}{l}\text { Založena na } \\
\text { empirických/pravděpodobnostních vztazích }\end{array} \\
\square \quad \begin{array}{l}\text { Založena na klinických úsudcích skupiny } \\
\text { expertů }\end{array}\end{array}$ \\
\hline 1.21 .6 & $\begin{array}{l}\text { Modifikovatelnost } \\
\text { Výstup zprávy je často fixní. Ale některé systémy vytvoří } \\
\text { výstup ve formě souboru, který mǔže uživatel dale } \\
\text { zpracovat. }\end{array}$ & $\begin{array}{ll}\square & \begin{array}{l}\text { Nemodifikovatelná (pouze fixní tištěný } \\
\text { výstup) }\end{array} \\
\square & \begin{array}{l}\text { Omezené modifikace (omezené na určité } \\
\text { oblasti, např. pole biografických dat) }\end{array} \\
\square & \begin{array}{l}\text { Neomezené modifikace (např. díky př́stupu } \\
\text { k dokumentu ve Wordu) }\end{array}\end{array}$ \\
\hline 1.21 .7 & 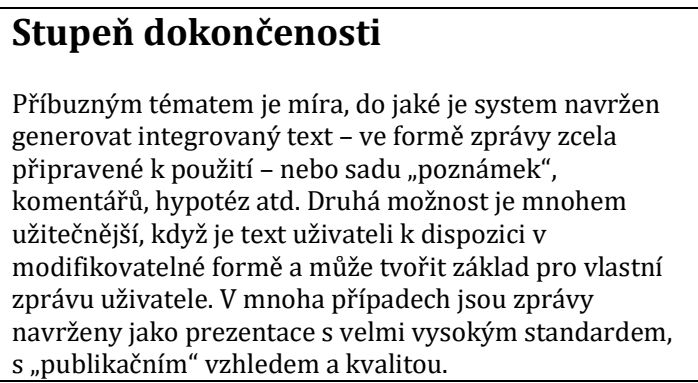 & $\begin{array}{ll}\square & \text { Publikační kvalita } \\
\bigotimes & \text { Kvalita pracovní verze }\end{array}$ \\
\hline
\end{tabular}




\begin{tabular}{|c|c|c|c|}
\hline 1.21 .8 & $\begin{array}{l}\text { Transparence } \\
\text { Systémy se liší svojí otevřeností nebo transparentností } \\
\text { vǔči uživateli. Otevřený system je ten, kde je spojení } \\
\text { mezi skórem škály a textem jasné a jednoznačné. Taková } \\
\text { otevřenost je možná pouze tehdy, když jsou } \\
\text { prezentovány jak texty, tak skóry, a spojení mezi nimi } \\
\text { explicitně uvedeno. Jiné systémy pracují jako “černé } \\
\text { skřriňky" a znesnadňují uživateli dát do vztahu skóry škál } \\
\text { a text. }\end{array}$ & 区 & $\begin{array}{l}\text { Jasné spojení mezi skóry konstruktů } \\
\text { a textem } \\
\text { Zatajené spojení mezi konstrukty, skóry } \\
\text { a textem } \\
\text { Směs jasných/zatajených spojení mezi } \\
\text { konstrukty, skóry a textem }\end{array}$ \\
\hline 1.21 .9 & $\begin{array}{l}\text { Styl a tón } \\
\text { Systémy se take liší v míře, do jaké nabízejí čtenáři } \\
\text { zprávy vedení nebo směr. Některé jsou deklarativní „Pan } \\
\text { X je velmi plachý a nebude dobrým prodejcem.... J Jiné } \\
\text { jsou navrženy tak, aby nabízely hypotézy nebo vznášely } \\
\text { otázky: „Na základě jeho skórŭ na škále Y se pan X zdá } \\
\text { být velmi plachým. Pokud je to tak, mohlo by pro něho } \\
\text { být obtí̌né pracovat v prostředí prodeje. Je nutné to } \\
\text { v jeho případě dale prozkoumat.” }\end{array}$ & $\begin{array}{l}\otimes \\
\square \\
\square\end{array}$ & $\begin{array}{l}\text { Direktivní } \\
\text { Hypotetizující } \\
\text { Jiné: }\end{array}$ \\
\hline 1.21 .10 & Zamýšlení příjemci & $\begin{array}{l}\bigotimes \\
\bigotimes \\
\square \\
\square \\
\square\end{array}$ & $\begin{array}{l}\text { Kvalifikovaní uživatelé testu } \\
\text { Osoby kompetentní vytvořit vlastní zprávy. } \\
\text { Kvalifikovaní uživatelé systému } \\
\text { Osoby, které nejsou kompetentní vytvořit samostatně } \\
\text { vlastní zprávy, ale mají trénink potřebný pro používání } \\
\text { zpráv generovaných systémem. } \\
\text { Respondenti testu } \\
\text { Respondent testu zpravidla nemá žádnou předchozí } \\
\text { znalost nástroje ani typu zprávy. } \\
\text { Třetí strany } \\
\text { Např. potenciální zaměstnavatel, rodič vedoucí či } \\
\text { supervizor apod. }\end{array}$ \\
\hline 1.22 & $\begin{array}{l}\text { Nabízejí distributoři službu opravy } \\
\text { a/nebo vývoje počítačových zpráv? }\end{array}$ & $\begin{array}{l}\square \\
\square\end{array}$ & $\begin{array}{l}\text { Ano } \\
\mathrm{Ne}\end{array}$ \\
\hline
\end{tabular}




\section{Č́st 5:}

\section{Nabídka, podmínky a náklady}

Tato část definuje, co vydavatel poskytne, komu, za jakých podmínek a za jaké ceny. Definuje podmínky kladené dodavatelem a týkající se toho, kdo smí a kdo nesmí získat materiál nástroje. Pokud jedna z možností neodpovídá podmínkám nabídky, doplňte popis relevantních podmínek.

\begin{tabular}{|c|c|c|}
\hline 1.23 & $\begin{array}{l}\text { Dokumentace poskytovaná } \\
\text { distributorem jako součást } \\
\text { testového balíku }\end{array}$ & 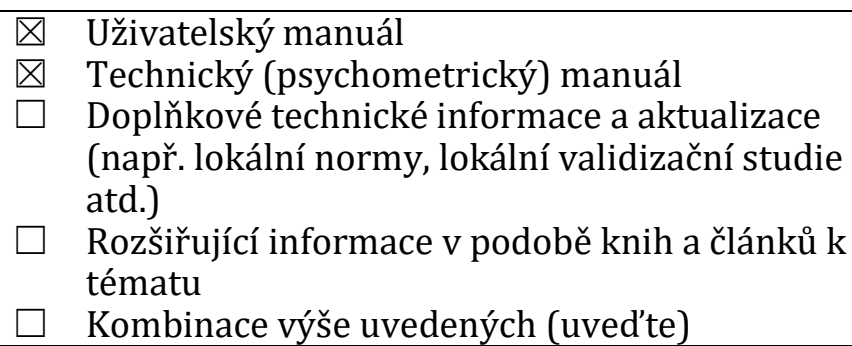 \\
\hline 1.24 & Metody publikace & $\begin{array}{ll} & \text { Papír } \\
\square & \text { PC - Diskety } \\
\square & \text { PC - CD/ROM } \\
\square & \text { Download z internetu } \\
\square & \text { Živý internet (nástroj pracuje v internetovém } \\
\text { prohlížeči) } \\
\text { Jiné: } \\
\quad \text { Součástí testovací aplikace }\end{array}$ \\
\hline 1.25 .1 & $\begin{array}{l}\text { Počáteční náklady. } \\
\text { Cena kompletní sady materiálů (všechny manuály a } \\
\text { další material nutný k aspon̆ jedné zkušební } \\
\text { administraci). Kolik uchazečú lze vyšetřovat pomocí } \\
\text { materiálù získaných za počáteční náklady, kde tyto } \\
\text { náklady zahrnují materially pro opakované vyšetření. }\end{array}$ & $\begin{array}{l}\text { Pro administraci testu je, stejně jako pro } \\
\text { administraci dalších testů v rámci Vídeňského } \\
\text { testového systému (VTS), nutno vlastnit základní } \\
\text { VTS SW. Jeho provoz se neobejde bez HW klíče } \\
\text { (přibližně } 2830 \text { Kč), roční licence je naceněna na cca } \\
7120 \text { Kč, neomezená licence pak na cca } 28500 \text { Kč. } \\
\text { Licence pro užívání samotného AMT pak přijde na } \\
\text { přibližně } 5990 \text { kč ( } 50 \text { administrací) nebo } 8980 \text { Kč } \\
\text { (roční licence). Uvedené ceny jsou dle vyjádření } \\
\text { lokálního distributora platné do } 1.10 .2018 \text {. } \\
\text { K provozu SW je nutno vlastnit prríslušné technické } \\
\text { vybavení, minimální i doporučené technické } \\
\text { parametry jsou k dispozici u lokálního distributora. }\end{array}$ \\
\hline 1.25 .2 & Opakující se náklady: & $\begin{array}{l}\text { Náklad na prodloužení roční licence VTS (bez nějž } \\
\text { nelze AMT administrovat) je shodný s pořizovacím } \\
\text { nákladem roční licence uvedeným výše. Ceny } \\
\text { shodné s těmi, uvedenými výše, platí také pro } \\
\text { prodloužení licence pro užívání AMT (jak ve } \\
\text { variantě pro } 50 \text { administrací, tak ve variantě roční } \\
\text { licence). }\end{array}$ \\
\hline 1.26 .1 & $\begin{array}{l}\text { Ceny za zprávy generované } \\
\text { softwarem nainstalovaným } \\
\text { uživatelem: }\end{array}$ & \\
\hline 1.26 .2 & $\begin{array}{l}\text { Ceny za vyhotovení zprávy zaslené } \\
\text { prostřednictvím pošty/faxu: }\end{array}$ & \\
\hline 1.26 .3 & $\begin{array}{l}\text { Ceny za vyhotovení zprávy zaslené } \\
\text { prostřednictvím internetové služby: }\end{array}$ & \\
\hline
\end{tabular}




\begin{tabular}{|c|c|c|}
\hline 1.27 & $\begin{array}{l}\text { Ceny za další služby a zpracování } \\
\text { dat: opravy nebo vývoj } \\
\text { automatických zpráv: }\end{array}$ & \\
\hline 1.28 & 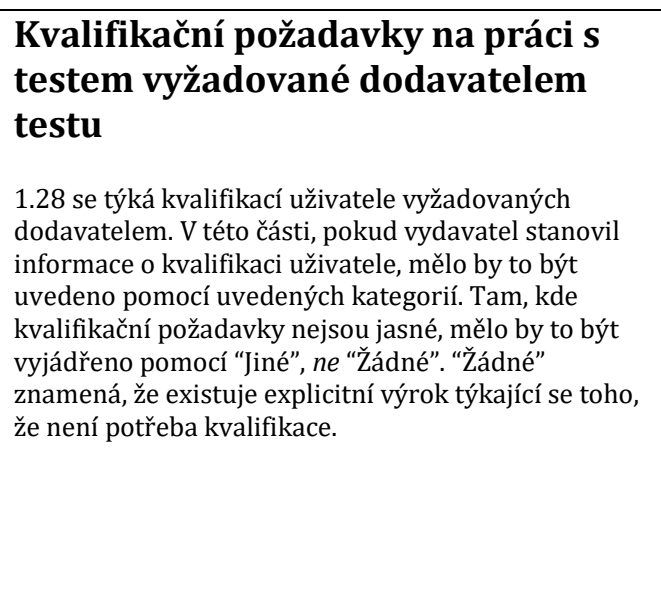 & $\begin{array}{l}\square \quad \text { Žádné } \\
\square \quad \text { Oprávnění (certifikát) pro specifický test } \\
\square \text { Oprávnění (certifikát) pro obecné výkonové } \\
\text { testy: i. e. míry maximálního výkonu ve } \\
\text { schopnostech } \\
\square \text { Potvrzení v testování obecných schopností a } \\
\text { dovedností: míry maximálního výkonu ve } \\
\text { vztahu k potenciálu k výkonu } \\
\square \text { Potvrzení v obecné diagnostice a diagnostice } \\
\text { osobnosti: míry typického chování, postojů a } \\
\text { preferencí } \\
\square \quad \text { Jiné: } \\
\quad \text { Není uvedeno }\end{array}$ \\
\hline 1.29 & 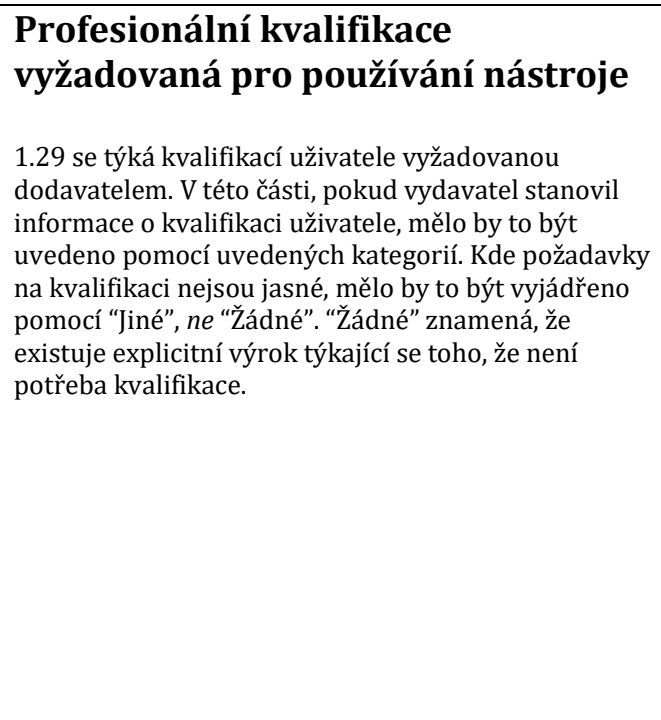 & $\begin{array}{ll} & \text { Žádné } \\
\square & \text { Praktický psycholog s kvalifikací v relevantní } \\
& \text { aplikační oblasti } \\
\square & \text { Praktický psycholog } \\
\square & \text { Výzkumný psycholog } \\
\square & \text { Nepsychologický akademický výzkumník } \\
\square & \text { Praktik v relevantních příbuzných profesích } \\
& \text { (terapie, medicína, poradenství, vzdělání, } \\
& \text { lidské zdroje atd.) } \\
\square & \text { Držitel Certifikátu způsobilosti pro testování } \\
& \text { v psychologii práce A BPS } \\
\square \quad \text { Držitel Certifikátu způsobilosti pro testování } \\
\text { v oblastni vzdělávacím A BPS } \\
\square \quad \text { Držitel Certifikátu způsobilosti pro testování } \\
\text { v psychologii práce B BPS } \\
\square \quad \text { Jiné: } \\
\quad \text { Není uvedeno }\end{array}$ \\
\hline
\end{tabular}


Č́st 6:

Hodnocení testových materiálů

\section{Vysvětlení hodnocení}

V následujících částech jsou celková posouzení adekvátnosti informací týkajících se validity, reliability a norem zobrazeny automaticky tučně.

Jakýkoli nástroj $s$ jedním nebo více posouzeními 0 nebo 2 týkajícími se atributů považovaných za kritické pro bezpečné používání nástroje, by neměl být považován za nástroj, který splňuje minimální standardy.

\begin{tabular}{|c|c|c|c|}
\hline $\begin{array}{l}\text { Vstup na posuzovacím } \\
\text { formuláři }\end{array}$ & $\begin{array}{l}\text { Posouzení podle } \\
\text { standardů EFPA }\end{array}$ & $\begin{array}{c}\text { Reprezentace recenze } v \\
\mathrm{UK}\end{array}$ & Vysvětlení \\
\hline [n/a] & [n/a ] & [n/a ] & $\begin{array}{l}\text { Tento atribut není u tohoto } \\
\text { nástroje použitelný }\end{array}$ \\
\hline $\mathbf{0}$ & {$[-]$} & [None ] & $\begin{array}{c}\text { Není možné posoudit jako } \\
\text { ne nebo nedostatek } \\
\text { poskytnutých informací }\end{array}$ \\
\hline $\mathbf{1}$ & {$[-1]$} & {$\left[\begin{array}{ll}* & ]\end{array}\right.$} & Neadekvátní \\
\hline 2 & & {$\left[\begin{array}{ll}* * & ]\end{array}\right.$} & NYNÍ NEPOUŽÍVÁNO \\
\hline 3 & {$\left[\begin{array}{ll}0 & ]\end{array}\right.$} & {$[* * *]$} & Adekvátní nebo přiměřený \\
\hline 4 & [ 1 ] & {$\left[{ }^{* * * *}\right]$} & Dobrý \\
\hline \multirow[t]{2}{*}{5} & [ 2 ] & {$[* * * * *]$} & Vynikající \\
\hline & & $\begin{array}{c}\text { [N.r.i.o.r] }{ }^{*} \text { (pouze pro } \\
\text { aktualizace) }\end{array}$ & $\begin{array}{l}\text { Položka nebyla v původní } \\
\text { recenzi posuzována }\end{array}$ \\
\hline
\end{tabular}

V této části má být provedeno více hodnocení různých aspektů nebo atributů dokumentace dodávané s nástrojem (nebo balíkem). Termín „dokumentace“ byl vybrán, aby pokrýval všechny ty materiály dodávané s nástrojem nebo snadno dostupné kvalifikovanému uživateli: např. manual administrátora; technické př́ručky; brožury s normami; dodatky k manuálu; aktualizace od vydavatelů/dodavatelů atd.

Položky mají být posuzovány n/a nebo 0 až 5 (poloviční rating je přijatelný)

Rating

\begin{tabular}{|c|c|c|}
\hline \multicolumn{2}{|c|}{$\begin{array}{l}\text { Kvalita vysvětlení principů, prezentace a kvalita poskytnuté informace: } \\
\text { (Tento celkový rating se získá použitím posouzení založeného na ratinzích daných pro položky } 2.1-2.8 \text { ) }\end{array}$} & 1 \\
\hline 2.1 & $\begin{array}{l}\text { Celkový rating kvality vysvětlení principů: (Tento celkový rating se získá použitím } \\
\text { posouzení založeného na hodnotách ratingů daných pro položky 2.1.1 - 2.1.5) }\end{array}$ & $\mathbf{0}$ \\
\hline 2.1.1 & i) Teoretické základy konstruktů: & 3 \\
\hline 2.1 .2 & ii) Procedura vývoje testu: & 0 \\
\hline 2.1 .3 & iii) Důkladnost analýz položek a model analýzy položek: & 0 \\
\hline 2.1 .4 & iv) Vysvětlení obsahové validity: & 0 \\
\hline 2.1 .5 & v) Souhrn relevantního výzkumu: & 3 \\
\hline 2.2 & 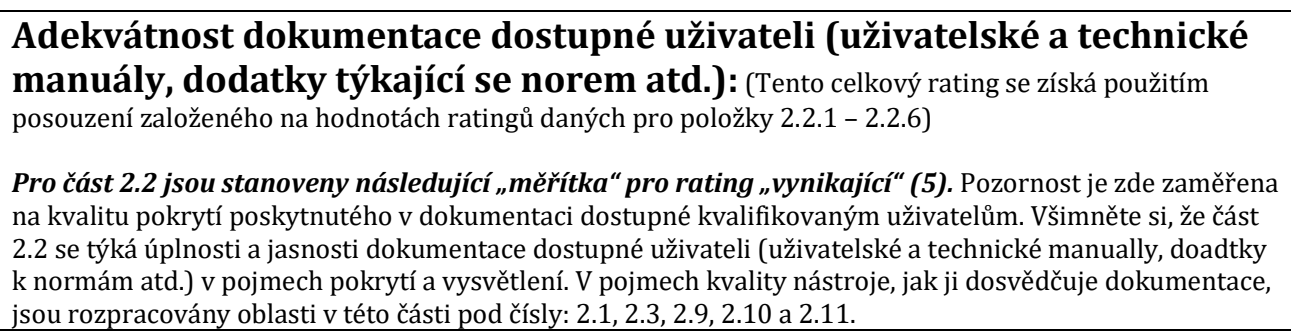 & 1 \\
\hline
\end{tabular}




\begin{tabular}{|c|c|c|}
\hline 2.2 .1 & $\begin{array}{l}\text { Principy: [viz 2.1] } \\
\text { Dobře argumentovaný a jasně prezentovaný popis toho, co má podle návrhu měřit a proč byl zkonstruován } \\
\text { tak, jak je. }\end{array}$ & 1 \\
\hline 2.2 .2 & $\begin{array}{l}\text { Vývoj: } \\
\text { Úplné detaily týkajíí́ se zdrojů položek, pilotáže, analýz položek, srovnávacích studií a změn prováděných v } \\
\text { průběhu vývojových pokusủ. }\end{array}$ & 1 \\
\hline 2.2 .3 & $\begin{array}{l}\text { Standardizace: } \\
\text { Jasné a detailní informace poskytnuté o velikostech a zdrojích standardizačního souboru a standardizační } \\
\text { proceduře. }\end{array}$ & 1 \\
\hline 2.2 .4 & $\begin{array}{l}\text { Normy: } \\
\text { Jasné a detailní informace poskytnuté o velikostech a zdrojích normalizačních skupin, podmínkách vyšetření } \\
\text { atd. }\end{array}$ & 1 \\
\hline 2.2 .5 & $\begin{array}{l}\text { Reliabilita: } \\
\text { Dobré vysvětlení reliability a široký rozsah měr vnitřní konsistence a retestu spolu s vysvětlením jejich } \\
\text { relevance a zobecnitelnosti nástroje vyšetření. }\end{array}$ & 3 \\
\hline 2.2 .6 & $\begin{array}{l}\text { Validita: } \\
\text { Dobré vysvětlení validity spolu s širokou škálou studií jasně a poctivě popsaných. }\end{array}$ & 1 \\
\hline 2.3 & $\begin{array}{l}\text { Kvalita procedurálních instrukcí poskytnutých uživateli: (Tento celkový rating se } \\
\text { získá s použitím posouzení na základě hodnot ratingů daných pro položky } 2.3 .1-2.3 .7 \text { ) }\end{array}$ & 1 \\
\hline 2.3 .1 & $\begin{array}{l}\text { Pro administraci testu: } \\
\text { Poskytnutá jasná a detailní vysvětlení a procedurální průvodce krok za krokem spolu s dobrými radami } \\
\text { týkajícícmi se otázek uchazeču a problémových situací. }\end{array}$ & 3 \\
\hline 2.3 .2 & $\begin{array}{l}\text { Pro skórování testu, normy atd.: } \\
\text { Poskytnuté jasné a detailní informace spolu s popsanými kontrolami pro vyhnutí se možným chybám } \\
\text { skórování. }\end{array}$ & {$[\mathrm{n} / \mathrm{a}]$} \\
\hline 2.3 .3 & $\begin{array}{l}\text { Pro interpretaci a vytváření zpráv: } \\
\text { Detailní doporučení týkající se interpretace různých skórů, chápání normativních měr a zacházení se vztahy } \\
\text { mezi různými škálami, s množstvím ilustrativních př́kladů a př́ipadových studií. }\end{array}$ & 3 \\
\hline 2.3 .4 & $\begin{array}{l}\text { Pro poskytnutí zpětné vazby a debriefingu respondentům testu a dalším: } \\
\text { Detailní doporučení, jak prezentovat zpětnou vazbu uchazečủm. }\end{array}$ & 1 \\
\hline 2.3 .5 & $\begin{array}{l}\text { Pro poskytování dobrých praktických témat týkajících se poctivosti a } \\
\text { zkreslení: } \\
\text { Uvedení detailních informací o studiích sexuálního a etnického zkreslení s relevantními varováními týkajícími } \\
\text { se používání a zobecňování validit. }\end{array}$ & 1 \\
\hline 2.3 .6 & $\begin{array}{l}\text { Omezení používání: } \\
\text { Jasné popisy, kdo by měl a kdo by neměl být vyšetřován spolu s dobře vysvětlenými odůvodněními těchto } \\
\text { omezení (např. typy nezpůsobilostí, požadované úrovně gramotnosti atd.). }\end{array}$ & 1 \\
\hline 2.3 .7 & $\begin{array}{l}\text { Reference a podpůrné materiály: } \\
\text { Detailní odkazy na relevantní podpůrnou akademickou literature a kř̌́žové odkazy na další příbuzné } \\
\text { materially týkající se diagnostických nástrojü. }\end{array}$ & 1 \\
\hline $\begin{array}{l}\text { Kva } \\
\text { (Ten }\end{array}$ & $\begin{array}{l}\text { Materiálů: } \\
\text { ový rating se získá použitím posouzení založeného na hodnotách ratingů pro položky } 2.4-2.8 \text { ) }\end{array}$ & 1 \\
\hline 2.4 & $\begin{array}{l}\text { Všeobecná kvalita materiálů testu } \\
\text { (testové brožury, odpověd'ové archy, testové objekty, software atd.): }\end{array}$ & 1 \\
\hline 2.5 & Kvalita lokální adaptace testu (pokud byl test přeložen a adaptován do místního jazyka): & 1 \\
\hline 2.6 & Snadnost, s jakou může respondent testu porozumět úkolu: & 5 \\
\hline 2.7 & $\begin{array}{l}\text { Snadnost, s jakou mohou být respondentem testu tvořeny reakce nebo } \\
\text { odpovědi: }\end{array}$ & 5 \\
\hline 2.8 & Kvalita položek: & 4 \\
\hline \multicolumn{3}{|c|}{$\begin{array}{l}\text { Recenzentovy komentáře týkající se dokumentace: } \\
\text { (komentáře principů, designu, vývoje testu a jeho přijatelnosti) }\end{array}$} \\
\hline \multicolumn{3}{|c|}{$\begin{array}{l}\text { Ačkoliv neexistuje mnoho explicitních důvodů, proč mít o kvalitách testu pochyb, je potřeba } \\
\text { poznamenat, že kvalita samotné dokumentace je velmi nízká. Samotný český manuál k metodě je zcela } \\
\text { nedostatečný a omezený, jeho anglicky psaná předloha však bohatstvím informací a dokladů o kvalitě } \\
\text { metody rovněž neoplývá. Zcela chybí podrobnější informace o vývoji testu a položkové analýze, stejně } \\
\text { jako ucelený souhrn důkazů obsahové a konstruktové validity. Chybí také podrobnější údaje o } \\
\text { průběhu standardizace či o výběru standardizačního i normalizačního souboru. Jakčesky, tak anglicky } \\
\text { psaný manuál odkazuje na publikaci, která tyto informace s největší pravědpodobností alespoň } \\
\text { částečně obsahuje, ta je nicméně psaná německy a nelze tedy očekávat, že lokální uživatel metody } \\
\text { bude mít k těmto informacím snadný přístup (nemluvě o tom, že publikace není volně dostupná). }\end{array}$} \\
\hline
\end{tabular}




\section{Č́st 7: \\ Hodnocení norem, reliability a validity}

Rating

Informace o normách nebo referenční skupině

\begin{tabular}{|c|c|c|}
\hline 2.9 & Celková adekvátnost: & 1,5 \\
\hline 2.9 .1 & $\begin{array}{cl}\begin{array}{l}\text { Vhodnost pro lokální použití, at' už pro lokální nebo mezinárodní normy: } \\
\text { [n/a] }\end{array} & \begin{array}{l}\text { Nepoužitelné } \\
0\end{array} \\
1 & \text { Žádná informace nepodána. } \\
3 & \begin{array}{l}\text { Není lokálně relevantní (např. nevhodné zahraniční výběry). } \\
\text { Lokální výběr z obecné populace nebo nelokální normy, které lze } \\
\text { použít s varováním. }\end{array} \\
4 & \begin{array}{l}\text { Výběry lokální země nebo relevantní mezinárodní výběry s dobrou } \\
\text { relevancí pro zamýšlenou aplikaci. }\end{array} \\
& \begin{array}{l}\text { Výběry lokální země nebo relevantní mezinárodní výběry vybrané z } \\
\text { dobře definovaných výběrů z relevantních aplikačních oblastí. }\end{array} \\
\end{array}$ & 3 \\
\hline 2.9 .2 & 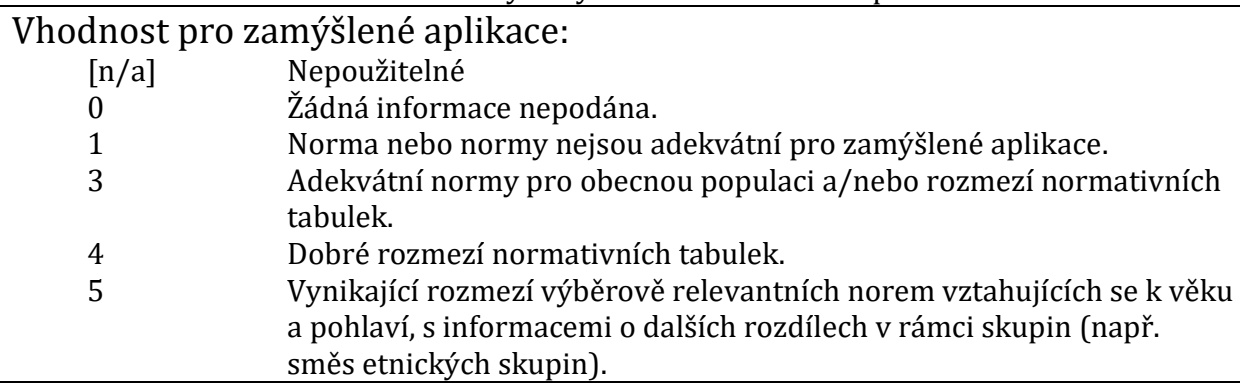 & 3 \\
\hline 2.9 .3 & 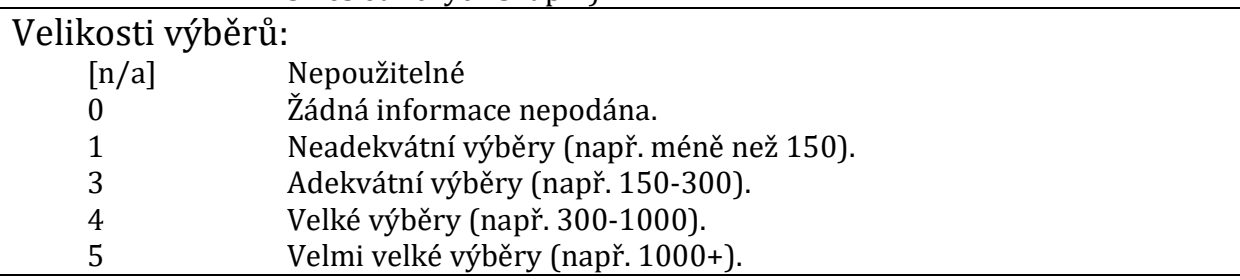 & 4 \\
\hline \begin{tabular}{|l|}
2.9 .4 \\
\end{tabular} & $\begin{array}{cl}\text { Procedury použité při výběru souboru: } \\
\quad \text { Žádná informace neposkytnuta } \\
\square & \text { Reprezentativní populaci [sumarizujte kritéria] } \\
\square & \text { Nahodilá } \\
\square & \text { Náhodná } \\
\end{array}$ & 0 \\
\hline \begin{tabular}{|l|l}
2.9 .5 \\
\end{tabular} & $\begin{array}{ll}\text { Kvalita informací poskytnutých o minoritní/chráněné skupině, rozdílech, } \\
\text { vlivech věku, rodu atd.: } \\
\begin{array}{ll}\text { [n/a] } & \text { Nepoužitelné } \\
0 & \text { Žádná informace nepodána. } \\
1 & \text { Neadekvátní informace. } \\
3 & \text { Adekvátní obecné informace s minimální analýzou. } \\
4 & \text { Dobré popisy a analýzy skupin a rozdílů } \\
5 & \text { Vynikajíć íérie analýz a diskuse o relevantních tématech vztahujících } \\
& \text { se k použití a interpretaci. } \\
\end{array} \\
\end{array}$ & 0 \\
\hline
\end{tabular}


2.9.6 Komentáře recenzentů k normám: Stručná zpráva o normách a jejich historii, včetně informací o doporučeních učiněných vydavatelem/autorem pro aktualizaci norem obvyklým způsobem.

Dle informací z anglické verze manuálu ( $\mathrm{v}$ české verzi informace o normách zcela chybí) byly normy vytvořeny na základě souboru 461 osob ve věku mezi 18 a 81 lety. Bližší informace o věkové struktuře chybí, uveden je pouze průměrný věk a směrodatná odchylka. Není známo, jakým způsobem byly osoby do souboru vybírány, je pouze známo, že sběr dat se uskutečnil v letech 2005 a 2006. Normy jsou obecné, bez věkové či jiné stratifikace.

\section{Validita}

\begin{tabular}{|c|c|c|}
\hline 2.10 & $\begin{array}{l}\text { Celková adekvátnost: (Tento celkový rating se získá na základě posouzení hodnot ratingů } \\
\text { daných v položkách } 2.10 .1-2.10 .2 .4 \text {. Neprůměrujte pouze čísla, abyste získali celkový rating. } \\
\text { Obvykle bude roven bud' konstruktové validitě nebo validitě vztahující se ke kritériu, podle } \\
\text { toho, která z nich je vyšší.) }\end{array}$ & 1 \\
\hline 2.10 .1 & $\begin{array}{l}\text { Konstruktová validita - celková adekvátnost } \\
\text { (Tento celkový rating se získá na základě posouzení hodnot ratingů daných v položkách } \\
\text { 2.10.1.2 - 2.10.1.6. Neprüměrujte pouze čísla, abyste tento celkový rating získali.) }\end{array}$ & 1 \\
\hline 2.10 .1 .1 & $\begin{array}{cl}\text { Použité plány: (zatrhněte tolik, kolik je jich použitelných) } \\
\square \quad \text { Žádná informace nepodána } \\
\square \quad \text { Korelace s dalšími nástroji a výkonovými kritérii } \\
\square \quad \text { Vnitroškálový (korelace položky se zbytkem) } \\
\square \quad \text { Rozdíly mezi skupinami } \\
\square \quad \text { Matice mnoha rysů a mnoha metod (MTMM) } \\
\square \quad \text { Explorační faktorová analýza } \\
\square \quad \text { Konfirmační faktorová analýza } \\
\square \quad \text { Experimentální plány } \\
\square \quad \text { Jiné: }\end{array}$ & \\
\hline 2.10 .1 .2 & 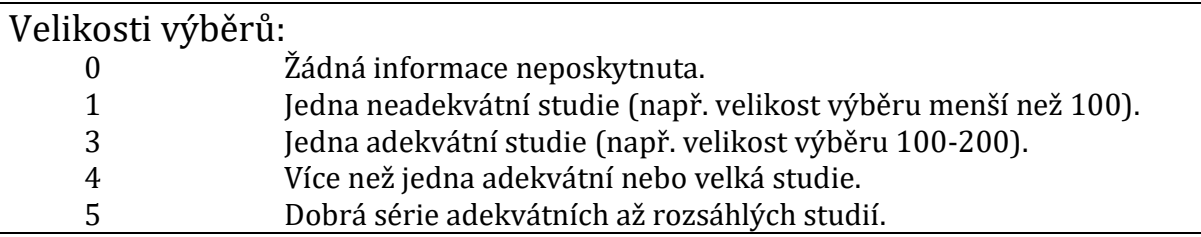 & 3 \\
\hline 2.10 .1 .3 & $\begin{aligned} \text { Procedura výběru souboru: } \\
\square \quad \text { Žadná informace neposkytnuta } \\
\square \quad \text { Reprezentativní vůči populaci [sumarizujte kritéria] } \\
\square \quad \text { Nahodilá } \\
\square \quad \text { Náhodná }\end{aligned}$ & \\
\hline 2.10 .1 .4 & $\begin{array}{cl}\text { Medián a rozsah korelací mezi testem a dalšími podobnými testy: } \\
0 & \text { Žádná informace neposkytnuta. } \\
1 & \text { Neadekvátní }(\mathrm{r}<0.55) . \\
3 & \text { Adekvátní }(0.55<\mathrm{r}<0.65) . \\
4 & \text { Dobrý }(0.65<\mathrm{r}<0.75) . \\
5 & \text { Vynikající }(\mathrm{r}>0.75) \\
\end{array}$ & 0 \\
\hline 2.10 .1 .5 & $\begin{array}{cl}\text { Kvalita nástrojů jako kritérií nebo markerů: } \\
0 & \text { Žádná informace neposkytnuta. } \\
1 & \text { Poskytnuta neadekvátní informace. } \\
3 & \text { Adekvátní kvalita. } \\
4 & \text { Dobrá kvalita. } \\
5 & \text { Vynikající kvalita s širokým rozsahem relevantních markerů pro } \\
& \text { konvergentní a divergentní validizaci. } \\
\end{array}$ & 0 \\
\hline 2.10.1.6 & $\begin{array}{cl}\begin{array}{c}\text { Analýzy diferenciálního fungování položek (DIF): } \\
{[\mathrm{N} / \mathrm{A}]}\end{array} & \text { Nepoužitelné } \\
0-5 & \text { hodnocení kvality DIF analýzy } \\
\end{array}$ & 0 \\
\hline 2.10 .2 & $\begin{array}{l}\text { Validita vztahující se ke kritériu - celková adekvátnost } \\
\text { (Tento celkový rating se získá na základě posouzení hodnot ratingů daných v položkách } \\
\text { 2.11.1 - 2.10.2.4. Neprüměrujte pouze čísla, abyste získali celkový rating.) }\end{array}$ & 3 \\
\hline
\end{tabular}




\begin{tabular}{|c|c|c|c|}
\hline 2.10 .2 .1 & $\begin{array}{c}\text { Popis po } \\
\square \\
\square \\
\square\end{array}$ & $\begin{array}{l}\text { džitých kritérií a charakteristik populací: (zatrhněte tolik, kolik je po } \\
\text { Souběžná } \\
\text { Prediktivní } \\
\text { Postdiktivní }\end{array}$ & \\
\hline 2.10 .2 .2 & $\begin{array}{c}\text { Velikost } \\
0 \\
1 \\
3 \\
4 \\
5\end{array}$ & $\begin{array}{l}\text { i výběrů: } \\
\text { Žádná informace neposkytnuta. } \\
\text { Jedna neadekvátní studie (např. velikost výběru menší než 100). } \\
\text { Jedna adekvátní studie (např. velikost výběru 100-200). } \\
\text { Jedna velká nebo vice než jedna adekvátně rozsáhlá studie. } \\
\text { Dobrá série adekvátních až rozsáhlých studií. }\end{array}$ & 4 \\
\hline 2.10 .2 .3 & $\begin{array}{l}\text { Procedur } \\
\text { (vyberte jec } \\
\quad \\
\square \\
\square \\
\square \\
\square\end{array}$ & $\begin{array}{l}\text { a výběru souboru: } \\
\text { Inu) } \\
\text { Žádná informace neposkytnuta } \\
\text { Účelná nebo reprezentativní } \\
\text { Nahodilá } \\
\text { Náhodná }\end{array}$ & \\
\hline 2.10 .2 .4 & $\begin{array}{c}\text { Medián a } \\
0 \\
1 \\
3 \\
4 \\
5\end{array}$ & $\begin{array}{c}\text { rozsah korelací mezi testem a kritérii: } \\
\text { Žádná informace neposkytnuta. } \\
\text { Neadekvátní (např. } \mathrm{r}<0.2 \text { ). } \\
\text { Adekvátní (např. } 0.2<\mathrm{r}<0.35 \text { ). } \\
\text { Dobrý (např. } 0.35<\mathrm{r}<0.50 \text { ). } \\
\text { Vynikající (např. } \mathrm{r}>0.50 \text { ) }\end{array}$ & 3 \\
\hline
\end{tabular}

Anglická verze manuálu je bohužel na informace o důkazech validity poměrně skoupá, v české variantě pak jakékoli informace zcela chybí. Stran obsahové validity autoři pouze odkazují na vlastní časopiseckou studii, která je však psána v německém jazyce a není volně dostupná. V manuálu parafrázují konkrétní zjištění - korelaci odhadnutých obtížností položek s konstrukčním kritériem (které samotné uvádí jako důkaz obsahové validity), které však v manuálu není žádným způsobem vysvětleno. Jako další důkaz konstruktové validity AMT odkazují autoři na studii $(\mathrm{N}=196)$, která se zabývala otázkou struktury inteligence (respektive ověřovala CHC model inteligence) a jako jednu z manifestních proměnných pro faktor fluidní inteligence používala právě AMT. Na tento dủkaz lze tedy nahlížet jako na variaci MTMM studie, avšak dle našeho soudu nelze tento zdroj považovat za samostatně uspokojivý důkaz konstruktové validity ATM (nehledě na to, že popis samotné studie zaujímá neúměrně velký prostor v manuálu). Co se kriteriální validity týče, anglicky psaný manuál odkazuje na dvě studie, ani v jednom př́ípadě však nelze hovořit o uspokojivém dủkazu kriteriální validity. $V$ jednom př́padě je AMT zmíněn jako součást testové baterie, která úspěšně diskriminuje mezi řidiči s historií nehod a bez ní (z těchto závěrů je usuzováno na kriteriální validitu), přičemž skór z AMT mírně pozitivně koreluje s celkovým zhodnocením řidičských schopností. $V$ druhém případě je AMT zmíněn opět jako součást testové baterie při zkoumání výkonu uchazečů na leteckém simulátoru, přičemž tato baterie je prezentována jako vysoce informativní prediktor úspěšnosti uchazeče v simulátorovém scénáři. Ani jeden důkaz však nelze považovat za standardní typ důkazu kriteriální validity testu obecné inteligence, respektive autoři metody v manuálu volbu obou indikátorů neargumentují. Ratingy jsou založeny rovněž na externích zdrojích (Risser at al., 2008; Sommer et al., 2008). 


\section{Reliabilita}

\begin{tabular}{|c|c|c|c|}
\hline 2.11 & $\begin{array}{l}\text { Celková adekve } \\
\text { (Tento celkový rating s } \\
\text { Neprüměrujte pouze }\end{array}$ & $\begin{array}{l}\text { Ǵtnost: } \\
\text { e získá na základě posouzení hodnot ratingů daných v položkách 2.11.1-2.10.2.4. } \\
\text { čisla, abyste získali celkový rating.) }\end{array}$ & 4 \\
\hline 2.11 .1 & \multicolumn{3}{|c|}{$\begin{array}{cl}\text { Poskytnutá data týkající se reliability: (vyberte jednu možnost) } \\
\quad \square \quad \text { Uveden pouze jeden koeficient reliability } \\
\square \quad \text { Uveden pouze jeden odhad standardní chyby měření } \\
\square \quad \text { Koeficienty reliability pro několik různých skupin } \\
\square \quad \text { Standardní chyba měření uvedená pro několik různých skupin } \\
\end{array}$} \\
\hline 2.11 .1 & \multicolumn{3}{|c|}{ Vnitřní konzistence: } \\
\hline 2.11 .1 .1 & \multicolumn{2}{|l|}{$\begin{array}{cc}\text { Velikost výběru: } \\
0 & \mathrm{~N} \\
1 & \mathrm{~J} \\
3 & \mathrm{~J} \epsilon \\
4 & \mathrm{~J} \epsilon \\
5 & \mathrm{D} \\
{[\mathrm{N} / \mathrm{A}]} & \mathrm{N} \\
\end{array}$} & 4 \\
\hline 2.11 .1 .2 & \multicolumn{2}{|c|}{$\begin{array}{cl}\text { Medián koeficientů: } \\
0 & \text { Neposkytnuta žádná informace. } \\
1 & \text { Neadekvátní (např. } r<0.7 \text { ) } \\
3 & \text { Adekvátní (např. } r=0.7 \text { až } 0.79 \text { ) } \\
4 & \text { Dobrý (např. r }=0.8 \text { až } 0.89 \text { ) } \\
5 & \text { Vynikající (např. r }>0.9 \text { ) } \\
{[\mathrm{N} / \mathrm{A}]} & \text { Nepoužitelné. } \\
\end{array}$} & 3 \\
\hline 2.11 .2 & \multicolumn{3}{|c|}{ Testová-retestová stabilita: } \\
\hline 2.11 .2 .1 & $\begin{array}{c}\text { Rozsah výběru: } \\
0 \\
1 \\
3 \\
4 \\
5 \\
\end{array}$ & $\begin{array}{l}\text { Neposkytnuta žádná informace. } \\
\text { Jedna neadekvátní studie (nap̌r. rozsah výběru menší než 100). } \\
\text { Jedna adekvátní studie (např. rozsah výběru 100-200). } \\
\text { Jedna rozsáhlá nebo vice než jedna adekvátné rozsáhlá studie. } \\
\text { Dobrá série adekvátních až rozsáhlých studií. }\end{array}$ & 1 \\
\hline 2.11 .2 .2 & $\begin{array}{c}\text { Medián koeficie } \\
0 \\
1 \\
3 \\
4 \\
5 \\
\end{array}$ & $\begin{array}{l}\text { ntů: } \\
\text { Neposkytnuta žádná informace. } \\
\text { Neadekvátní (např. } r<0.6 \text { ) } \\
\text { Adekvátní (např. } r=0.6 \text { až } 0.69 \text { ) } \\
\text { Dobrý (např. } r=0.7 \text { až } 0.79 \text { ) } \\
\text { Vynikající (např. } r>0.8 \text { ) }\end{array}$ & 3 \\
\hline 2.11 .3 & \multicolumn{3}{|c|}{ Reliabilita jako ekvivalence: } \\
\hline 2.11.3.1 & \begin{tabular}{|l} 
Rozsah výběru: \\
0 \\
1 \\
3 \\
4 \\
5 \\
{$[\mathrm{~N} / \mathrm{A}]$} \\
\end{tabular} & $\begin{array}{l}\text { Neposkytnuta žádná informace. } \\
\text { Jedna neadekvátní studie (např. rozsah výběru menší než 100). } \\
\text { Jedna adekvátní studie (např. rozsah výběru 100-200). } \\
\text { Jedna rozsáhlá nebo vice než jedna adekvátně rozsáhlá studie. } \\
\text { Dobrá série adekvátních až rozsáhlých studií. } \\
\text { Nepoužitelné. }\end{array}$ & 0 \\
\hline 2.11 .3 .2 & $\begin{array}{l}\text { Medián koeficie } \\
0 \\
1 \\
3 \\
4 \\
5 \\
{[\mathrm{~N} / \mathrm{A}]}\end{array}$ & $\begin{array}{l}\text { ntů: } \\
\text { Neposkytnuta žádná informace. } \\
\text { Neadekvátní (např. r }<0.6 \text { ) } \\
\text { Adekvátní (např. r }=0.6 \text { až } 0.69 \text { ) } \\
\text { Dobrý (např. r = } 0.7 \text { až } 0.79 \text { ) } \\
\text { Vynikající (např. r>0.8) } \\
\text { Nepoužitelné }\end{array}$ & 0 \\
\hline \multicolumn{4}{|c|}{$\begin{array}{l}\text { 2.11.4 Komentáře recenzentů k reliabilitě: } \\
\text { - Komentujte intervaly spolehlivosti pro koeficienty reliability } \\
\text { - Uved'te Spearmanovy-Brownovy ekvivalenty }\end{array}$} \\
\hline \multicolumn{4}{|c|}{$\begin{array}{l}\text { Vzhledem k adaptivnímu charakteru testu je možno předem zvolit zamýšlenou reliabilitu (respektive } \\
\text { chybu odhadu latentního skóru), a to selekcí jedné z nabízených předdefinovaných forem testu. } \\
\text { Nabízené úrovně reliability jsou } 0,70,0,83 \text { a } 0,86 \text {. Anglická verze manuálu také uvádí dvě hodnoty } \\
\text { test-retestové reliability získané prostřednictvím studie o } \mathrm{N}=82 \text { - stabilitu po třech měsících, } \\
\mathrm{r}=0,62 \text {, a retestovou reliabilitu } \mathrm{r}=0,74 \text {. Ve druhém případě se patrně jedná o opakovanou } \\
\text { administraci ihned po administraci první (v tom případě by se jednalo o poměrně nízké číslo), avšak } \\
\text { manuál tento údaj žádným způsobem neupřesňuje. }\end{array}$} \\
\hline
\end{tabular}




\section{Část 8:}

\section{Kvalita počítačově generovaných zpráv:}

Položky mají být posuzovány n/a nebo 0 až 5 (poloviční rating je přijatelný)

\begin{tabular}{|c|c|c|}
\hline 2.12 & $\begin{array}{l}\text { Celková adekvátnost počítačově generovaných zpráv: } \\
\text { (Tento celkový rating se získá na základě posouzení hodnot ratingů daných pro položky 2.12.1-2.12.7. } \\
\text { Neprüměrujte pouze hodnoty, abyste získali celkový rating.) }\end{array}$ & 5 \\
\hline 2.12 .1 & 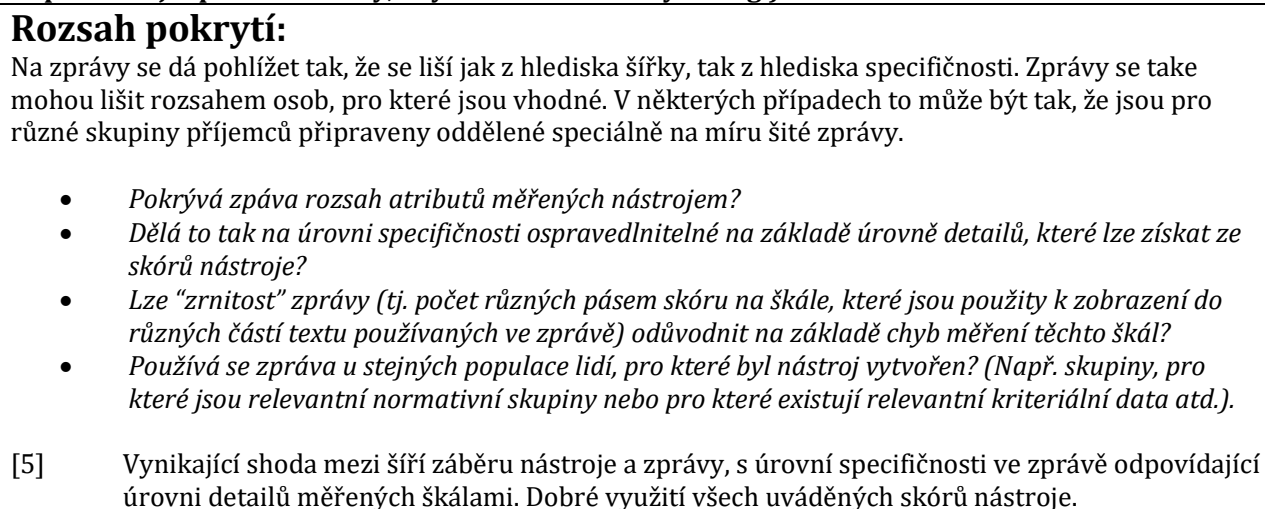 & 5 \\
\hline 2.12 .2 & $\begin{array}{l}\text { Reliabilita } \\
\text { • Jak konsistentní jsou zprávy ve své interpretaci podobných sad skórů? } \\
\text { - } \quad \begin{array}{l}\text { Pokud je obsah zprávy variabilní (např. náhodným výběrem z ekvivalentních částí textu), je to } \\
\text { prováděno uspokojivě? }\end{array} \\
\text { - Je interpretace skóru a rozdílů mezi skóry ospravedlnitelná z hlediska chyb měření škál? } \\
\text { [5] } \quad \begin{array}{l}\text { Vynikající konsistence při interpretaci a přiměřená varování poskytnutá u tvrzení, interpretací } \\
\text { a doporučení týkajících se souvisejících chyb měření. }\end{array}\end{array}$ & 5 \\
\hline 2.12 .3 & $\begin{array}{l}\text { Relevance neboli validita } \\
\text { Spojení mezi nástrojem a obsahem zprávy může být bud' vysvětlena v rámci zprávy nebo dokumentováno } \\
\text { odděleně. Kde jsou zprávy založené na klinickém úsudku, by měl být dokumentován process, kterým } \\
\text { expert(i) vytvářel(i) obsah a pravidla dávající do vztahu skóry a obsah. } \\
\text { - Jak silný je vztah mezi obsahem zprávy a skóry nástroje? Do jaké míry jde zpráva za nebo se } \\
\text { rozchází s informacemi poskytovanými skóry nástroje? } \\
\text { - Je obsah zprávy v jasném vztahu k charakteristikám měřeným nástrojem? } \\
\quad \begin{array}{l}\text { Poskytuje rozumné závěry o kritériích, ke kterým mǔžeme očekávat, že budou takové } \\
\text { charakteristiky ve vztahu? }\end{array} \\
\text { - Jaké empirické důkazy jsou poskytnuty, které ukazují, že tyto vztahy skutečně existují? } \\
\text { Je relevantní uvažovat jak o konstruktové validitě zprávy (tj. miře, do jaké poskytuje interpretaci, která je } \\
\text { ve shodě s příslušnými konstrukty) a kriteriální validitě (tj. kde jsou formulovány výroky, které lze davit } \\
\text { zpětně do vztahu s empirickými daty). } \\
\text { [5] }\end{array}$ & 5 \\
\hline 2.12 .4 & $\begin{array}{l}\text { Spravedlnost neboli nezávislost na systematickém zkreslení } \\
\text { • Mohl by obsah zprávy a použitý jazyk vytvářet dojem nepatřičnosti pro určité skupiny? } \\
\text { - Vyjasňuje zpráva jakékoli oblasti možného zkreslení ve výsledcích nástroje? } \\
\quad \text { Jsou k dispozici formy v alternativních jazycích? Pokud ano, byly podniknuty adekvátní kroky k } \\
\text { zajištění jejich ekvivalence? } \\
\text { [5] Vynikající, jasná varování a vysvětlení možného zkreslení, dostupné ve všech relevantních } \\
\text { uživatelských jazycích }\end{array}$ & 3 \\
\hline 2.12 .5 & $\begin{array}{l}\text { Přijatelnost } \\
\text { Ta bude velmi záviset na komplexnosti jazyka použitého ve zprávě, složitosti popisovaných konstruktů a } \\
\text { účelu, pro jaký je určena. } \\
\text { • Dá se očekávat, že forma a obsah zprávy budou přijatelné zamýšleným př́íjemcưm? } \\
\text { - Je zpráva napsána jazykem, který je přiměřený pravděpodobným úrovním počtářské zběhlosti a } \\
\text { gramotnosti předpokládaného čtenáře? } \\
\text { [5] Velmi vysoká přijatelnost, dobře navržená a dobře se hodící předpokládaným př́ijemcủm }\end{array}$ & 5 \\
\hline
\end{tabular}




\begin{tabular}{|c|c|c|}
\hline 2.12 .6 & $\begin{array}{l}\text { Praktičnost } \\
\text { Otázky praktičnosti take ovlivňují přijatelnost. Hlavní praktická výhoda počítačově generovaných zpráv je } \\
\text { ta, že šetří čas osoby, která by jinak musela zprávu vytvořit. Když tato osoba není koncový uživatel, } \\
\text { argumenty týkající se praktičnosti mohou být obtížněji formulovatelné. } \\
\text { • Kolik času šetří každá zpráva uživateli? } \\
\text { • Kolik času zabere čtení a použivání každé zprávy? } \\
\text { [5] } \quad \text { Vynikající z hlediska efektivity a hodnoty. }\end{array}$ & 5 \\
\hline 2.12 .7 & 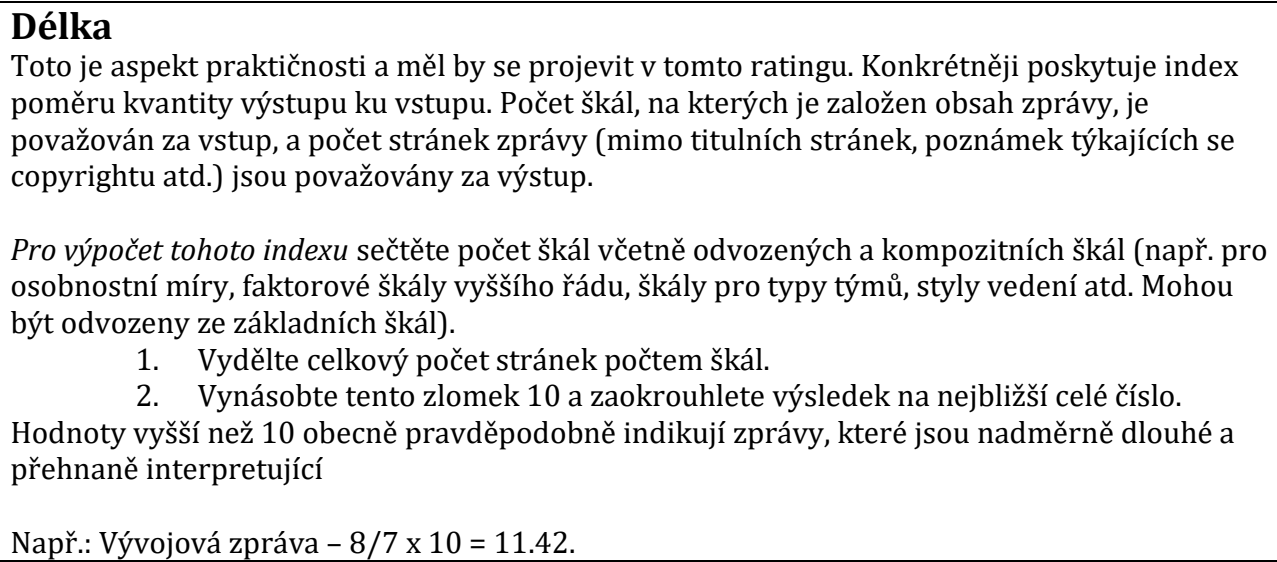 & 20 \\
\hline
\end{tabular}

Generovaná „zpráva“, která je zde posuzována, není zprávou v pravém slova smyslu, ale spíše výstupem obsahujícím odhadnutý skór testované osoby spolu s dalšími proměnnými (percentilový ekvivalent, délka testování, počet administrovaných položek, průběh testování, atd.). V postatě neobsahuje interpretace (pouze ve velmi stručné podobě) ani syntézu informací $z$ více škál (metoda se zabývá pouze jedním konstruktem). Uvedená délka této zprávy je nadhodnocena množstvím tabulek a grafů, které mohou, ale nemusí být v této zprávě př́tomny dle vlastního uvážení administrátora.

\section{Č́st 9:}

\section{Závěrečné hodnocení:}

\subsection{Hodnotící zpráva testu:}

Tato část by měla obsahovat stručné, jasně obhájené posouzení nástroje/produktu. Mělo by popisovat jeho pro a proti a poskytnout určitá obecná doporučení týkající se toho, jak a kdy by se měl používat - spolu s varováními (kde jsou potřebná) týkajícími se případů, kde by se používat neměl.

Test AMT je určen k měření obecné inteligence ve smyslu inteligence fluidní a je určen pro neklinické populace dospělého a adolescentního věku. Test je určený $\mathrm{k}$ použitít v řadě aplikačních oblastí, od výběru zaměstnanců přes dopravní psychologii až po edukační a karierně-poradenské kontexty. Administrace testu je relativně rychlá (typicky do 60 minut), avšak délka administrace se může podstatně lišit vzhledem k adaptivnímu charakteru testu a vzhledem $\mathrm{k}$ tomu, že $\mathrm{k}$ dispozici je několik forem, které se liší požadovanou přesností měření (jedna z forem je rovněž časově omezena na dobu administrace 20 minut). Nejpřesnější (a průměrně nejdelší) z forem slibuje poměrně vysokou reliabilitu ve smyslu vnitřní konzistence $(0,86)$, adaptivita testu také může sloužit k udržení optimální úrovně probandovy motivace. Administrace testu je relativně jednoduchá, stejně jako nároky na ovládání počítačového rozhraní probandem a jeho porozumění obsahu testu. Test byl standardizován na souboru 1356 rakouských respondentů, normy byly vytvořeny za pomoci souboru o velikosti 461 respondentů z téhož prostředí, bez věkové stratifikace. Test využívá řady předností moderních psychometrických postupů (adaptivní testování, dosažení shodné úrovně přesnosti měření nezávisle na úrovni měřeného rysu, ochrana položkové banky před nadměrnou expozicí apod.) a pro administrátora testu je uživatelsky př́ijemnou metodou. 
Test, respektive testová př́ručka, která je spolu s testem $\mathrm{k}$ dispozici (jak v české, tak anglické verzi), však trpí řadou nedostatků. Česká verze manuálu je z hlediska poskytování úplných a kvalitních informací pro uživatele testu zcela nedostatečná. Chybí informace o reliabilitě vyjma vnitřní konzistence, důkazech validity, normách, procesu vývoje testu a jednotlivých položek či informace spojené s položkovou analýzou. Česká verze manuálu obsahuje řadu chyb, překlepů a formálních nedostatků, místy působí až jako strojový překlad anglické verze př́ručky. Pro uživatele testu, který stojí o získání potřebných informací v českém jazyce, je manuál naprosto nedostačujícím zdrojem. $\mathrm{Z}$ tohoto důvodu se $\mathrm{v}$ rámci posudku věnujeme manuálu anglickému - ani ten však není závažných (ale i formálních) nedostatků zcela prostý.

Snad největším nedostatkem jsou chybějící či neúplné informace o teoretických principech metody a o jejím vývoji, včetně konstrukce a analýzy položek. Autoři testu odkazují na vlastní časopisecký článek, ve kterém má být řada těchto informací uvedena, avšak tento článek je publikován v placeném periodiku a je psán v německém jazyce. Pro českého uživatele bez znalosti německého jazyka (kterou v žádném př́padě nelze paušálně očekávat) je tedy manuál jako zdroj těchto informací nedostačující. Stejné výtky lze adresovat směrem $\mathrm{k}$ absenci přesvědčivých důkazů o validitě metody. Jedinými prezentovanými důkazy o validitě jsou odkazy na studie, provedené jinými autory, než kteří metodu vyvíjeli, a to ještě v nedostatečném rozsahu, což čtenáři znemožňuje posoudit důkazy o validitě metody. Obsahová validita je téměř nekomentována, důkaz o konstruktové validitě je představen pouze ve formě odkazu na jedinou studii, která však nemůže dostatečné důkazy o konstruktové validitě poskytnout. Jedná se totiž o výzkum struktury inteligence ve formě testování různých faktorových modelů (skór z AMT figuruje jako jedna z pozorovaných proměnných). Kriteriální validita je dokazována odkazy na studie dvě, z nichž však ani jedna neposkytuje kritéria vhodná k posouzení validity testu fluidní inteligence (jedním z kritérií je nehodovost řidičů a řidičské schopnosti, druhým z kritérií je výkon osob v leteckém simulátoru). Externě dostupné časopisecké studie důvěru ve vysokou kriteriální validitu testu př́liš nezvyšují.

Podobně chybí také informace o proceduře standardizace testu, včetně postupu konstrukce standardizačního i normalizačního vzorku. Manuál se rovněž nevěnuje otázce férovosti testu či diferenciálního fungování položek, tuto problematiku pouze shrnuje konstatováním, že „dosavadní zkušenosti indikují, že test AMT je férový“, bez jakékoli podpory pro toto tvrzení.

\subsection{Závěry:}

Na AMT lze ocenit inovativnost, příjemnost použití, adaptivní povahu a (tušené) solidní racionále pro tvorbu položek a předpokládané fungování testu. Testové materiály jsou však neadekvátní a působí nedokončeným dojmem - především česká verze manuálu, kterou rozhodně nelze doporučit pro užívání. 0 validitě testu nemůže být uživatel na základě poskytnutých informací zcela přesvědčen, problematické je však také použití norem. V českém prostředí by byl proband srovnáván s nejasně specifikovanou skupinou osob testovaných v Rakousku, a s největší pravděpodobností by jeho výkon nebyl férově srovnáván s pro něj vhodnou referenční skupinou. $Z$ uvedených důvodů tedy doporučujeme užívat test AMT jen velmi obezřetně k orientačnímu měření fluidní inteligence - alespoň do chvíle, kdy bude manuál testu doplněn o informace, které získání důvěry v deklarované kvality testu náležitě podpoří. 


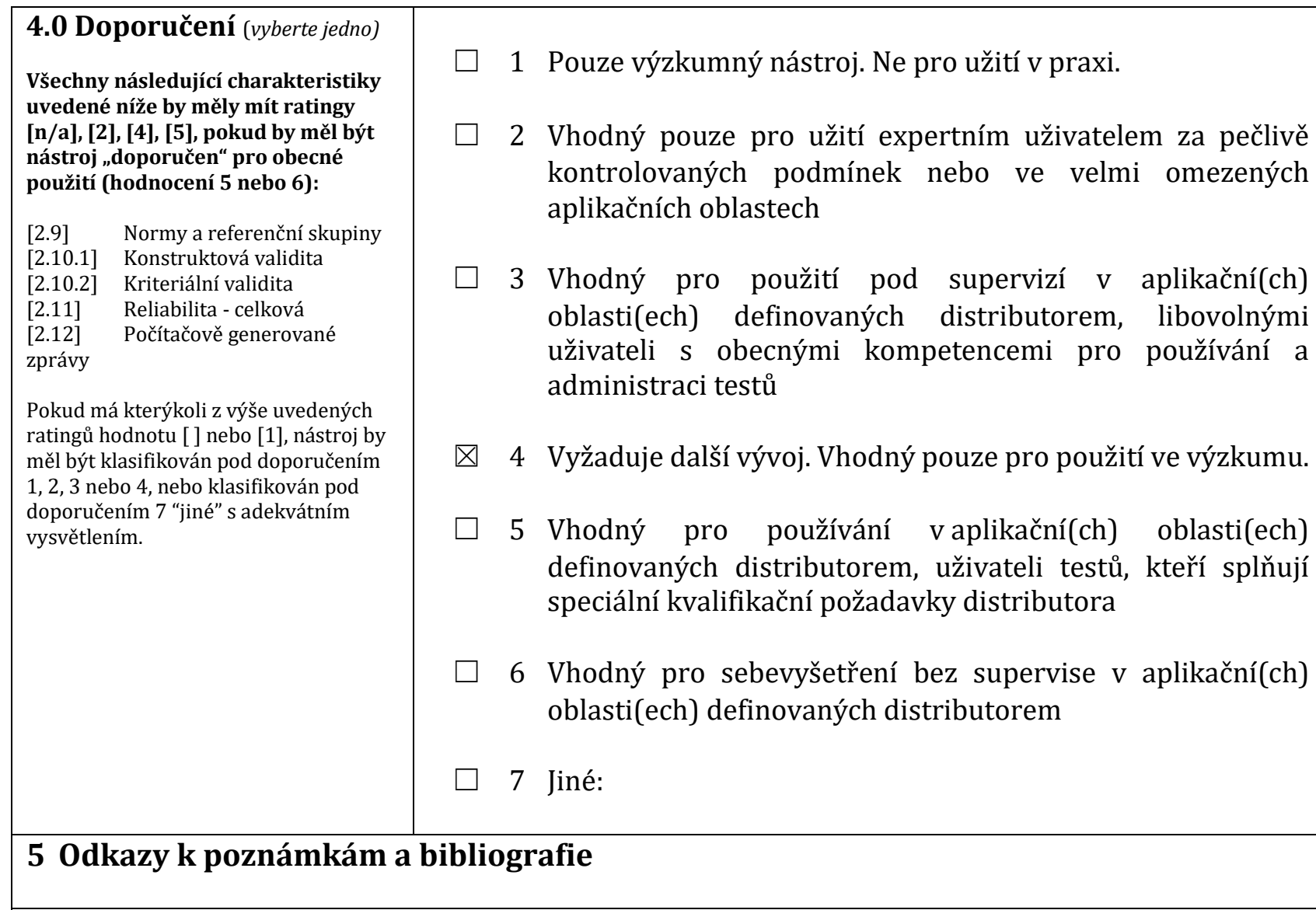

Carroll, J. B. (1993). Human cognitive abilities: A survey of factor-analytic studies. Cambridge, England: Cambridge University Press.

Risser, R., Chaloupka, C., Grundler, W., Sommer, M., Häusler, J., \& Kaufmann, C. (2008). Using non-linear methods to investigate the criterion validity of traffic-psychological test batteries. Accident Analysis \& Prevention, 40(1), 149-157.

Sommer, M. \& Arendasy, M. (2005). Theory-based construction and validation of a modern computerized intelligence test battery. Budapest: EAPA 2005 Abstracts.

Sommer, M., Herle, M., Häusler, J., Risser, R., Schützhofer, B., \& Chaloupka, C. (2008). Cognitive and personality determinants of fitness to drive. Transportation Research Part F: Traffic Psychology and Behaviour. http://doi.org/10.1016/j.trf.2008.03.001

\section{Měřené konstrukty:}

Obecná inteligence 